\title{
Magnesium Implants: Prospects and Challenges
}

\author{
Parama Chakraborty Banerjee ${ }^{1, *}$, Saad Al-Saadi ${ }^{2}$, Lokesh Choudhary ${ }^{2}{ }^{\oplus}$, \\ Shervin Eslami Harandi ${ }^{2}$ and Raman Singh ${ }^{1,2}$ (D) \\ 1 Department of Chemical Engineering, Monash University, Clayton, VIC 3800, Australia; \\ raman.singh@monash.edu \\ 2 Department of Mechanical and Aerospace Engineering, Monash University, Clayton, VIC 3800, Australia; \\ saad.al-saadi@monash.edu (S.A.-S.); lokesh.gdu@gmail.com (L.C.); shervin.harandi@monash.edu (S.E.H.) \\ * Correspondence: parama.banerjee@monash.edu; Tel.: +61-3-99054174
}

Received: 7 September 2018; Accepted: 27 December 2018; Published: 3 January 2019

\begin{abstract}
Owing to their suitable mechanical property and biocompatibility as well as the technological possibility of controlling their high corrosion rates, magnesium and its alloys have attracted significant attention as temporary bio-implants. Though the ability of magnesium to harmlessly biodegrade and its inherent biocompatibility make magnesium alloys a suitable choice for a temporary implant, their high corrosion rates limit their practical application, as the implants can potentially corrode away even before the healing process has completed. Different approaches, such as alloying, surface modification, and conversion coatings, have been explored to improve the corrosion resistance of various magnesium alloys. However, the corrosion behavior of magnesium implants with and without a surface modification has been generally investigated under in-vitro conditions, and studies under in-vivo conditions are limited, which has contributed to the lack of translation of magnesium implants in practical applications. This paper comprehensively reviews the prospects of magnesium alloy implants and the current challenges due to their rapid degradation in a physiological environment. This paper also provides a comprehensive review of the corrosion mitigation measures for these temporary implants.
\end{abstract}

Keywords: magnesium alloy; implant; corrosion

\section{Introduction}

The significant advancement in medical science and technology has considerably improved the quality and longevity of human life. The development of a variety of biomaterials is among the most notable innovations. Biomaterials are inorganic or organic materials that are designed to mimic physiological components and/or processes. Based on the material-host tissue interaction, biomaterials can be broadly classified into three categories [1]: (i) biotolerant materials; (ii) bioactive materials; and (iii) bioinert materials.

Implants are a type of biomaterials that are typically inserted into a host tissue to induce desired cellular behaviour and restore any impaired physical functions [2]. The application of implants varies depending on various requirements [3], such as (i) the healing and stabilization of the fractured bones by using screws, rods, and plates; (ii) the rectification of deformities, such as an abnormal spinal curvature; (iii) an improvement in the function of an organ and/or other parts of human body; and (iv) the replacement of a damaged and/or diseased part of the anatomy, such as damaged arthritic joints and malfunctioning heart valves.

The applicability of implants in a physiological environment mandates that they possess (i) excellent biocompatibility, requiring an adequate biological response; (ii) good mechanical properties; (iii) excellent corrosion resistance; and (iv) high resistance to fatigue $[4,5]$. Depending on their 
applications (such as orthopaedic, oral/dental, or cardiovascular), implants can be of different types. Table 1 shows the commonly used implants.

Table 1. Classification of different types of traditional implant materials.

\begin{tabular}{cc}
\hline Types of Implants & Materials Used \\
\hline Metal & Titanium alloys, stainless steel, gold alloys, cobalt-Chromium alloys, platinum electrodes \\
Polymers & Poly(methyl-methacrilate), Polyethylenes, polypropelenes, polyamides, polyesters, hydrogels \\
Ceramics & Alumina, Zirconia, hydroxiapatite, porceins, phosphates, bioactive glass \\
Composites & Poly(methyl-methacrilate)-glass fibers, Bisphenol-A-glycidyl-methacrylate-quartz/silica fillers \\
\hline
\end{tabular}

Among the various types of implant materials, metallic implants are widely used as orthopaedic, cardiovascular, and, in some cases, as oral implants. The traditional implant materials, including stainless steels, titanium alloys, and cobalt-chromium alloys, possess good resistance to corrosion, wear, and fatigue along with excellent load-bearing capabilities. However, it is well-known that these alloys also contribute to various negative effects, including stress shielding [6] and inflammation of local tissues due to a potential release of cytotoxic ions [7]. Additionally, when used as temporary implants (such as plates, screws, and wires) [8], a second surgery is generally required to remove the implant after the tissues have healed, which leads to increasing patient morbidity and healthcare costs $[9,10]$. Thus, implant materials that 'biocorrode', such as magnesium alloys, are currently attracting significant interest [11]. In this review, the required properties of temporary implants are discussed with a focus on magnesium-alloy-based temporary implants. The prospects and challenges of using magnesium-alloy-based implants are discussed in the following sections.

\section{Temporary Implants}

The low degradation rate of traditional implants has made them unsuitable for temporary implant applications, which has led to the rapid development of biodegradable implants. Polymers and metals are two material classes that have been widely considered for biodegradable temporary applications due to their inherent ability to dissolve away harmlessly within the human body, which eliminates the necessity of the removal of the implant after it has served its purpose [9,12]. In fact, during the healing process, the mechanical stiffness/strength of the temporary implants slowly decreases, while the surrounding tissue regains stiffness/strength (as shown in Figure 1). Harmless dissolution of the implant material eliminates the need for a second surgery that is commonly employed for removal of the implant once the tissue has completely healed [13].

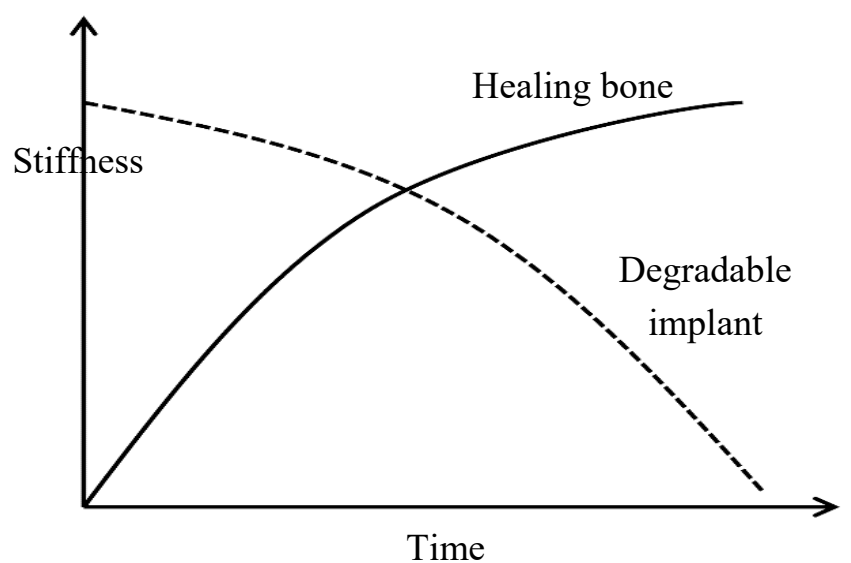

Figure 1. The gradual decrease in stiffness of a biodegradable magnesium implant and concurrent healing of the bone. Obtained from [13], with permission from Woodhead Publishing, 2018.

Polymer-based temporary bi-implants are commercially available, and, in general, are made of either natural polymers (such as collagen, alginate, agarose, chitosan, fibrin) or synthetic polymers 
(such as poly-glycolic acid, poly-lactic acid, and poly-dioxanone) [14,15]. The principal advantage with polymer-based implants is that their microstructure and chemistry can be tailored easily to control their degradation rate in a physiological environment [15]. However, the mechanical properties of these polymers drastically decrease in a physiological environment, which limits their use as load-bearing implants. Typical degradation kinetics of a common poly-lactic acid-based implant in a chloride environment [16] are shown in Table 2. It is evident from Table 2 that the compressive strength and compressive modulus of the polymeric implants significantly decrease over time when immersed in a chloride environment. In this context, metal-based implants generally possess superior mechanical properties (Table 3), and are more suitable for most of the implant applications that involve load-bearing conditions. In fact, Wong et al. [17] have reported that the compressive strength of a magnesium-based metallic implant was $200 \mathrm{MPa}$ after 4 weeks of immersion in simulated body fluid (SBF).

Table 2. Degradation of a polymer-based implant over time in $0.154 \mathrm{M}$ sodium chloride [16].

\begin{tabular}{ccccc}
\hline Material & Immersion Time (days) & Compressive Modulus (MPa) & Compressive Strength (MPa) & Fracture Strain (\%) \\
\hline Poly-lactic acid & 0 & $200 \pm 45$ & $14 \pm 5$ & $30 \pm 9$ \\
Poly-lactic acid & 3 & $22 \pm 3$ & $5 \pm 3$ & $35 \pm 8$ \\
Poly-lactic acid & 14 & $39 \pm 9$ & $4 \pm 2$ & $32 \pm 2$ \\
\hline Material & Immersion Time (days) & Compressive Modulus (MPa) & $14 \pm 5$ & Fracture Strain (\%) \\
\hline Poly-lactic acid & 0 & $200 \pm 45$ & $5 \pm 3$ & $30 \pm 9$ \\
Poly-lactic acid & 3 & $22 \pm 3$ & $4 \pm 2$ & $35 \pm 2$ \\
Poly-lactic acid & 14 & $39 \pm 9$ & & $32 \pm 2$ \\
\hline
\end{tabular}

Magnesium and its alloys have attracted significant attention as a temporary implant due to their excellent biocompatibility with human physiology. In fact, magnesium is essential to the human metabolism as a cofactor for many enzymes [18,19], and magnesium ions $\left(\mathrm{Mg}^{++}\right)$are well-known to facilitate tissue-healing [20]. Additionally, extra $\mathrm{Mg}^{++}$does not cause cellular toxicity in the human body and is generally expelled along with urine [21].

Even though good mechanical properties are essential for implants (especially orthopaedic implants), excessive stiffness of the traditional metallic implants can be detrimental to the healing bones or tissues as it can cause stress shielding [6]. Stress shielding occurs when a healing bone experiences stresses below a threshold as a result of the excessive stiffness of the implant material [6,22]. Figure 2a shows a radiograph of a femur in which significant bone loss was visible around the proximal end of the implant (indicated by the circled areas in Figure 2a) as a result of stress shielding [23]. Additionally, the reduction in the stress in the bone in the proximal region of the implant is sometimes accompanied by an increased stress in the distal regions. This results in deposition of additional bone due to increased stress transfer in the distal region (as is indicated by a rectangle in Figure 2b) [23].
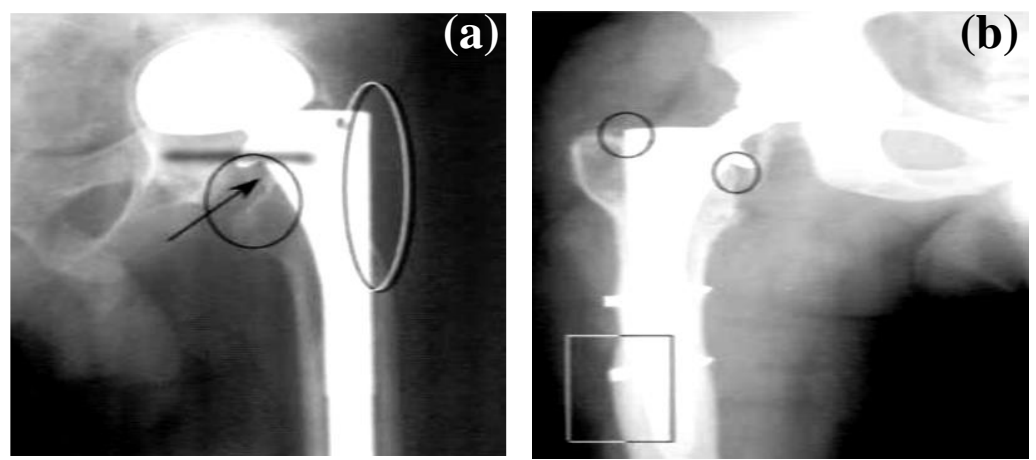

Figure 2. Radiographs of hip implants showing changes in bone mass due to stress shielding around an implant: (a) bone loss at the proximal region (indicated in the circled regions at the edge of the prosthesis) and (b) bone deposition (indicated by the rectangle) in the distal region of the implant . Obtained from [23], with permission from Wiley online library, 2018. 
In this context, the mechanical properties of magnesium and its alloys, i.e., low density $\left(1.74-2.0 \mathrm{~g} / \mathrm{cm}^{3}\right)$ and elastic modulus (41-45 GPa), are more suitable for implant applications [9,21]. Table 3 presents a comparison of the mechanical properties of magnesium alloys, the traditional implant alloys, and natural bone $[9,21]$. It is evident from Table 3 that the density, elastic modulus, and yield strength of magnesium alloys are respectively the closest to those of natural bone. Therefore, magnesium alloys can significantly reduce the stress-shielding-related problems of orthopaedic/cardiovascular implants, and, most critically, in the situations of high-load-bearing implants.

Table 3. A comparison of the mechanical properties of various metallic implants with natural bone [24].

\begin{tabular}{cccccc}
\hline Property & Natural Bone & $\begin{array}{c}\text { Magnesium } \\
\text { Alloys }\end{array}$ & $\begin{array}{c}\text { Titanium } \\
\text { Alloys }\end{array}$ & $\begin{array}{c}\text { Cobalt-Chromium } \\
\text { Alloys }\end{array}$ & $\begin{array}{c}\text { Stainless } \\
\text { Steels }\end{array}$ \\
\hline Density $\left(\mathrm{g} / \mathrm{cm}^{3}\right)$ & $1.8-2.1$ & $1.74-2.0$ & $4.4-4.5$ & $8.3-9.2$ & $7.9-8.1$ \\
Elastic modulus $(\mathrm{GPa})$ & $3-20$ & $41-45$ & $110-117$ & 230 & $189-205$ \\
Yield strength $(\mathrm{MPa})$ & $130-180$ & $85-190$ & $758-1117$ & $450-1000$ & $170-310$ \\
\hline
\end{tabular}

In summary, magnesium implants offer several advantages, including (i) biocompatibility and osteogenesis [9,25-28], (ii) biodegradability and avoidance of a second surgery [18-21], (iii) favourable mechanical properties [9,21,24], (iv) machinability and dimensional stability [29], and (v) a high damping capacity [30].

\section{Corrosion: The Major Drawback of Magnesium Implants}

Despite their highly advantageous properties, magnesium and its alloys are not commonly used as degradable implants. The major drawback of magnesium alloys as implants is their exceptionally high corrosion rate in the physiological environment [19,31-34]. The high corrosion rates promote fast degradation of the mechanical properties, leading to the premature failure of implants before the completion of the tissue-healing process [34,35]. Additionally, hydrogen evolution, which is the principal cathodic reaction and concurrent with the corrosion of magnesium alloys [36-40], can significantly interfere with the healing process $[10,41]$.

Human body fluid consists of water, electrolytic ions, proteins (such as albumins, globulins, and fibrinogen), and dissolved oxygen. Being the most electronegative engineering metal (with an electrochemical potential of $-2.3 \mathrm{~V}$ versus a standard hydrogen electrode), magnesium is highly susceptible to corrosion in most aqueous environments, including human body fluid. Corrosion of magnesium produces an oxide/hydroxide layer on the surface, which is not protective in most aqueous environments. The following reactions represent the corrosion of magnesium alloys in most aqueous environments, including the physiological environment.

$$
\begin{gathered}
\text { Anodic reaction : } \mathrm{Mg}_{(s)} \rightarrow \mathrm{Mg}_{(a q)}^{2+}+2 e^{-} \\
\text {Cathodic reaction : } 2 \mathrm{H}_{2} \mathrm{O}_{(a q)}+2 e^{-} \rightarrow 2 \mathrm{OH}_{(a q)}^{-}+\mathrm{H}_{2(g)} \\
\text { Overall reaction: } \mathrm{Mg}(s)+2 \mathrm{H}_{2} \mathrm{O}_{(a q)} \rightarrow \mathrm{Mg}(\mathrm{OH})_{2(s)}+\mathrm{H}_{2(g)}
\end{gathered}
$$

Even though the formed hydroxide layer covers the surface of magnesium, this hydroxide layer is not stable in the presence of chloride ions in human body fluid. The presence of chloride ions quickly converts the hydroxide layer into highly soluble magnesium chloride [42].

$$
\mathrm{Mg}(\mathrm{OH})_{2(s)}+2 \mathrm{Cl}_{(a q)}^{-} \rightarrow \mathrm{MgCl}_{2}+2 \mathrm{OH}_{(a q)}^{-}
$$

The disappearance of the hydroxide layer due to chloride ions hastens the corrosion of magnesium alloys. Additionally, hydrogen gas $\left(\mathrm{H}_{2}\right)$ evolution during magnesium corrosion can create subcutaneous gas bubbles [43] and gas bubbles adjacent to the implants, which can cause the separation of tissues and/or tissue layers [36]. In-vitro studies report the critical tolerance level of 
hydrogen to be $<0.01 \mathrm{~mL} / \mathrm{cm}^{2} /$ day, and this has been widely used to screen magnesium alloys for temporary implant applications [36]. However, it should be noted that each alloy must be investigated in-vivo in relation to the intended function. In this context, it may be interesting to note that a few in-vivo studies $[28,44]$ have reported the evolved hydrogen-forming gas pockets only in the first week post-surgery, which gradually disappear over a period of $2-3$ weeks post-surgery. Thus, it may be reasonable to assume that hydrogen evolution may not significantly interfere with the healing process as long as the corrosion rates of the magnesium implants are appropriately controlled in the first couple of weeks, such that the hydrogen evolution rate remains lower than $0.01 \mathrm{~mL} / \mathrm{cm}^{2} /$ day.

In order to identify ways to improve the corrosion resistance of magnesium implants, it is important to investigate their corrosion rates and mechanisms in the presence of a physiological environment. In-vitro corrosion of magnesium alloys has been widely investigated in a variety of simulated physiological solutions, which is summarized in the following sections.

\section{In-Vitro Corrosion of Magnesium Implants in Various Simulated Physiological Environments}

Corrosion of magnesium alloys significantly depends on the ions present in the electrolyte. Magnesium alloy corrosion has been investigated in a variety of in-vitro electrolytes that mimic the composition of the physiological fluid. Depending on the various ion concentrations in these electrolytes, different corrosion rates and mechanisms have been observed for a variety of magnesium implants [45-48]. The most commonly employed in-vitro electrolytes are Hank's solution, Ringer's solution, Dulbecco's Modified Eagle's Medium (DMEM), phosphate-buffered saline (PBS), original simulated body fluid, conventional simulated body fluid (c-SBF), ionized simulated body fluid (i-SBF), revised simulated body fluid (r-SBF), and modified simulated body fluid (m-SBF) [45-47]. It is evident from Table 4 that the composition and the ion concentrations significantly vary among these in-vitro electrolytes. It is to be noted here that a variety of buffers, including $\mathrm{HEPES}$, Tris- $\mathrm{HCl}$, and $\mathrm{HCO}_{3}{ }^{-}$, are used in these in-vitro electrolytes, which can consume the $\mathrm{OH}^{-}$ions generated during magnesium corrosion, and, thereby, significantly alter the true corrosion rate of magnesium implants in in-vitro systems [48].

Among the in-vitro electrolytes, various SBFs have been extensively used due to their close similarities in composition with blood plasma (i.e., the inorganic ion concentration as shown in Table 4). Additionally, SBF can promote bone-like apatite formation on a variety of substrates [49-51]. Among other in-vitro electrolytes, Hank's balanced salt solution (HBSS) is one of the most prominent ones. HBSS has high nutritional value [52] and is generally used in biomedical research to support a variety of cell cultures [19]. One of the major differences between SBF and HBSS is the presence of a buffering additive in the case of SBF. In general, the buffering additives can form complexes with calcium ions $\left(\mathrm{Ca}^{2+}\right)[53,54]$, which interferes with the corrosion process of a metallic implant [55]. 
Table 4. A comparison of the composition of the blood plasma with the most commonly used simulated in-vitro electrolytes [56].

\begin{tabular}{|c|c|c|c|c|c|c|c|c|c|c|c|}
\hline \multicolumn{2}{|c|}{ Quantity of Ions and Organic Components } & \multirow{2}{*}{$\begin{array}{c}\text { Blood Plasma } \\
142\end{array}$} & \multirow{2}{*}{$\begin{array}{c}\text { Hanks' Solution } \\
142\end{array}$} & \multirow{2}{*}{$\begin{array}{c}\text { Ringer's Solution } \\
130\end{array}$} & \multirow{2}{*}{$\begin{array}{c}\text { DMEM } \\
1273\end{array}$} & \multirow{2}{*}{$\begin{array}{c}\text { PBS } \\
157\end{array}$} & \multirow{2}{*}{$\begin{array}{c}\text { Original SBF } \\
142\end{array}$} & \multirow{2}{*}{$\begin{array}{c}\text { c-SBF } \\
142\end{array}$} & \multirow{2}{*}{$\begin{array}{c}\mathbf{r}-\mathrm{SBF} \\
142\end{array}$} & \multirow{2}{*}{$\begin{array}{c}\text { i-SBF } \\
142\end{array}$} & \multirow{2}{*}{$\begin{array}{c}\mathbf{m}-\mathrm{SBF} \\
142\end{array}$} \\
\hline $\mathrm{Na}^{+}$ & $\left(\mathrm{mmol} \mathrm{L}^{-1}\right)$ & & & & & & & & & & \\
\hline $\mathrm{K}^{+}$ & $\left(\mathrm{mmol} \mathrm{L}^{-1}\right)$ & 5 & 5.9 & 4 & 5.3 & 4.1 & 5 & 5 & 5 & 5 & 5 \\
\hline $\mathrm{Ca}^{+}$ & $\left(\mathrm{mmol} \mathrm{L}^{-1}\right)$ & 2.5 & 1.3 & 1.4 & 1.8 & - & 2.5 & 2.5 & 2.5 & 1.6 & 2.5 \\
\hline $\mathrm{Mg}^{2+}$ & $\left(\mathrm{mmol} \mathrm{L}^{-1}\right)$ & 1.5 & 0.8 & - & 0.8 & - & 1.5 & 1.5 & 1.5 & 1 & 1.5 \\
\hline $\mathrm{HCO}_{3}^{-}$ & $\left(\mathrm{mmol} \mathrm{L}^{-1}\right)$ & 27 & 4.2 & - & 44.1 & - & 4.2 & 4.2 & 27 & 27 & 10 \\
\hline $\mathrm{Cl}^{-}$ & $\left(\mathrm{mmol} \mathrm{L}^{-1}\right)$ & 103 & 145 & 109 & 90.8 & 140 & 148.8 & 147.8 & 103 & 103 & 103 \\
\hline $\mathrm{HPO}_{4}{ }^{2-}$ & $\left(\mathrm{mmol} \mathrm{L}^{-1}\right)$ & 1 & 0.8 & - & 0.9 & 11.5 & 1 & 1 & 1 & 1 & 1 \\
\hline $\mathrm{SO}_{4}{ }^{2-}$ & $\left(\mathrm{mmol} \mathrm{L}^{-1}\right)$ & 0.5 & 0.8 & - & 0.8 & _ & 0 & 0.5 & 0.5 & 0.5 & 0.5 \\
\hline Buffer & - & - & - & - & HEPES & - & Tris & Tris & HEPES & HEPES & HEPES \\
\hline Amino acids & $\left(\mathrm{g} \mathrm{L}^{-1}\right)$ & - & - & - & 1.6 & - & - & - & - & - & - \\
\hline Glucose & $\left(\mathrm{g} \mathrm{L}^{-1}\right)$ & $0.65-1.1$ & $\overline{1}$ & - & 4.5 & - & - & - & - & - & - \\
\hline Albumin & $\left(\mathrm{g} \mathrm{L}^{-1}\right)$ & $30-55$ & _- & - & - & - & - & - & - & - & - \\
\hline$\alpha$-globulins & $\left(\mathrm{g} \mathrm{L}^{-1}\right)$ & $5-10$ & - & - & - & - & - & - & - & - & - \\
\hline$\beta$-globulins & $\left(\mathrm{g} \mathrm{L}^{-1}\right)$ & $6-12$ & - & - & - & - & - & - & - & - & - \\
\hline$\gamma$-globulins & $\left(\mathrm{g} \mathrm{L}^{-1}\right)$ & $6.6-15$ & - & - & - & - & - & - & - & - & - \\
\hline$\alpha_{1}$-lipoproteins & $\left(\mathrm{g} \mathrm{L}^{-1}\right)$ & $6-12$ & - & - & - & - & - & - & - & - & - \\
\hline Fibronogen & $\left(\mathrm{g} \mathrm{L}^{-1}\right)$ & $1.7-4.3$ & - & - & - & - & - & - & - & - & - \\
\hline cholesterol & $\left(\mathrm{g} \mathrm{L}^{-1}\right)$ & $1.2-2.5$ & - & - & - & - & - & - & - & - & - \\
\hline Fatty acids & $\left(\mathrm{g} \mathrm{L}^{-1}\right)$ & $1.9-4.5$ & - & - & - & - & - & - & - & - & _- \\
\hline Lactate & $\left(\mathrm{mmol} \mathrm{L}^{-1}\right)$ & $0.5-2.2$ & - & - & - & - & - & - & - & - & - \\
\hline Urea & $\left(\mathrm{mmol} \mathrm{L}^{-1}\right)$ & $3-7$ & - & - & - & - & - & - & - & - & - \\
\hline
\end{tabular}

DMEM, Dulbecco's Modified Eagle's Medium; PBS, phosphate-buffered saline; SBF, simulated body fluid; c-SBF, conventional SBF; r-SBF, revised SBF; i-SBF, ionized SBF; m-SBF, modified SBF. 


\subsection{Influence of Inorganic Ions Present in the In-Vitro Electrolytes}

The nature of the inorganic ions present in the in-vitro electrolytes (Table 4) can significantly affect the corrosion rate of magnesium implants. In general, a hydroxide layer $\left(\mathrm{Mg}(\mathrm{OH})_{2}\right)$ that forms on a magnesium alloy's surface is rapidly dissolved in the presence of chloride ions $\left(\mathrm{Cl}^{-}\right)[57,58]$. The high $\mathrm{Cl}^{-}$concentrations in blood plasma as well as in the in-vitro electrolytes explain the rapid corrosion of magnesium implants. Sulphate ions $\left(\mathrm{SO}_{4}{ }^{2-}\right)$ are also well-known to accelerate the corrosion of magnesium implants. On the other hand, bicarbonate ions $\left(\mathrm{HCO}_{3}{ }^{-}\right)$in appreciable quantities $\left(>27 \mathrm{mmol} \mathrm{L}^{-1}\right)$ can form an insoluble carbonate, which can passivate the magnesium's surface [48]. Low concentrations of phosphate ions $\left(\mathrm{HPO}_{4}{ }^{2-}\right)$ can also decelerate magnesium corrosion by the formation of insoluble and dense phosphates. In addition to these anions, inorganic cations can also affect the corrosion of magnesium in the in-vitro electrolytes [36]. Song et al. [36] reported that the presence of calcium ions and phosphate ions can lead to the formation of calcium phosphate, which, when precipitated on the magnesium's surface, can significantly retard the corrosion kinetics.

\subsection{Influence of Organic Components Present in the In-Vitro Electrolytes}

Even though the electrolytes in most of the in-vitro studies did not contain organic components, the actual blood plasma does contain them in appreciable quantities. Hence, it is important to understand the influence of the most prominent organic components present in blood plasma on the corrosion resistance of magnesium alloys. Proteins, glucose, fatty acids, and cholesterol are the most common organic components in blood plasma. Proteins are well-known to adsorb on a metal's surface and can retard the corrosion of a metallic implant [59], as also reported by Yamamoto et al. [60]. They attributed this to the adsorption of protein on the metallic implant surfaces, which acts as a corrosion barrier, and significantly reduces the corrosion rate of magnesium implants. However, Harandi et al. [22] reported that protein (bovine serum albumin) adsorbs on the implant's surface during the initial hours of immersion, but, with increasing time of immersion in the Hank's solution, the protein chelates with the corrosion products, causing a disruption of the protective film and, thus, accelerating the corrosion of the metallic implant.

\section{Protective Coatings to Improve the Corrosion Resistance of Magnesium Implants}

Various strategies, including alloying [61], surface modification using energetic radiation [62,63], and conversion coatings [64], have been employed to improve the corrosion resistance of magnesium alloys. Among these, the application of conversion coatings is the most widely used strategy. Biocompatibility and good barrier properties are the key criteria that a coating must satisfy in order for the coated magnesium alloys to be used as implants. In the following section, different conversion coatings that have been developed to improve the corrosion resistance of magnesium implants are summarized.

\subsection{Biodegradable Polymeric Coatings}

A variety of biodegradable polymers, including poly-lactic acid (PLA) [65], poly(lactic-co-glycolic acid) [66], and polycaprolactone (PCL) [67], have been used to improve the corrosion resistance of magnesium implants. Alabbasi et al. [65] spin-coated polylactic acid (PLA) onto AZ21 magnesium alloy and reported that this coating significantly improved the corrosion resistance of this alloy in simulated body fluid. The corrosion resistance ( $\mathrm{Rp}$, as shown in Figure 3 ) increased while the adhesion of the coating decreased with the increasing coating thickness. 


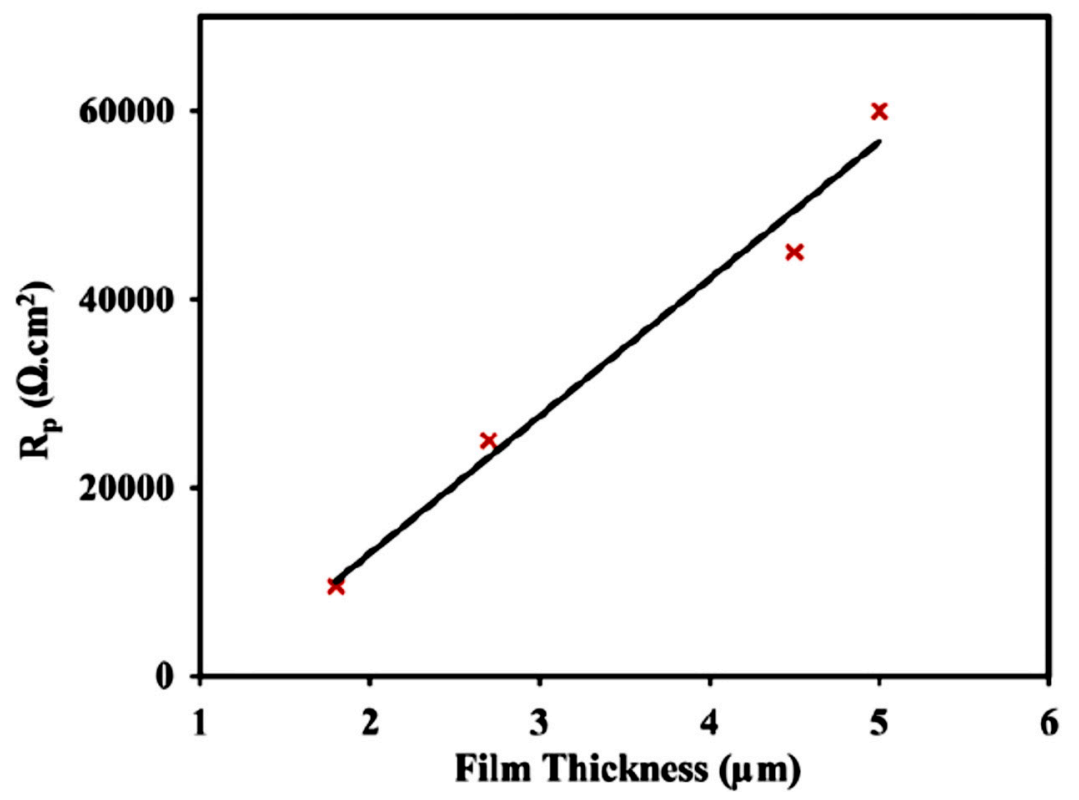

Figure 3. The increase in corrosion resistance of the poly-lactic acid (PLA)-coated AZ21 alloy with increasing coating thickness. Obtained from [65], with permission from Thin Solid Films, Elsevier, 2018.

Ostrowski et al. [66] investigated a poly(lactic-co-glycolic acid) polymer coating on AZ31 and Mg4Y magnesium alloys. The application of the poly(lactic-co-glycolic acid) polymer film resulted in a lower $\mathrm{I}_{\text {corr }}$ and a less negative $\mathrm{E}_{\text {corr }}$ of the polymer-coated $\mathrm{Mg}$ alloys pre-exposed to Dulbecco's modified Eagle's medium (DMEM). Although the concentrations of the magnesium ions reduced during the first 3 days of immersion of the polymer-coated AZ31 and Mg4Y alloys in DMEM, the ion concentrations increased with a further increase in the duration of immersion (Figure 4). As shown in Figure 4 [66], both uncoated and coated AZ31 respectively possess a higher resistance to corrosion compared to the $\mathrm{Mg} 4 \mathrm{Y}$ alloy.

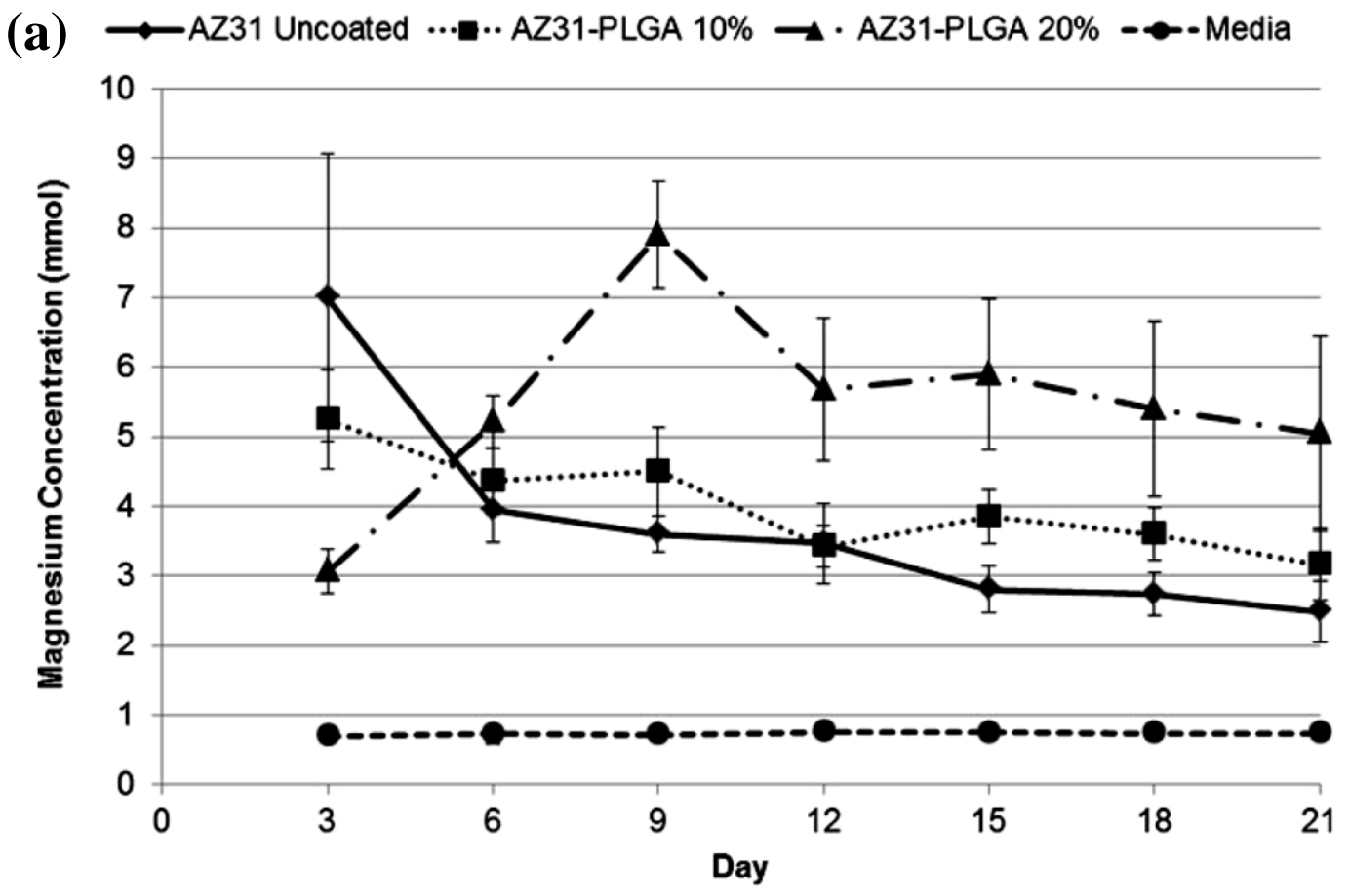

Figure 4. Cont. 


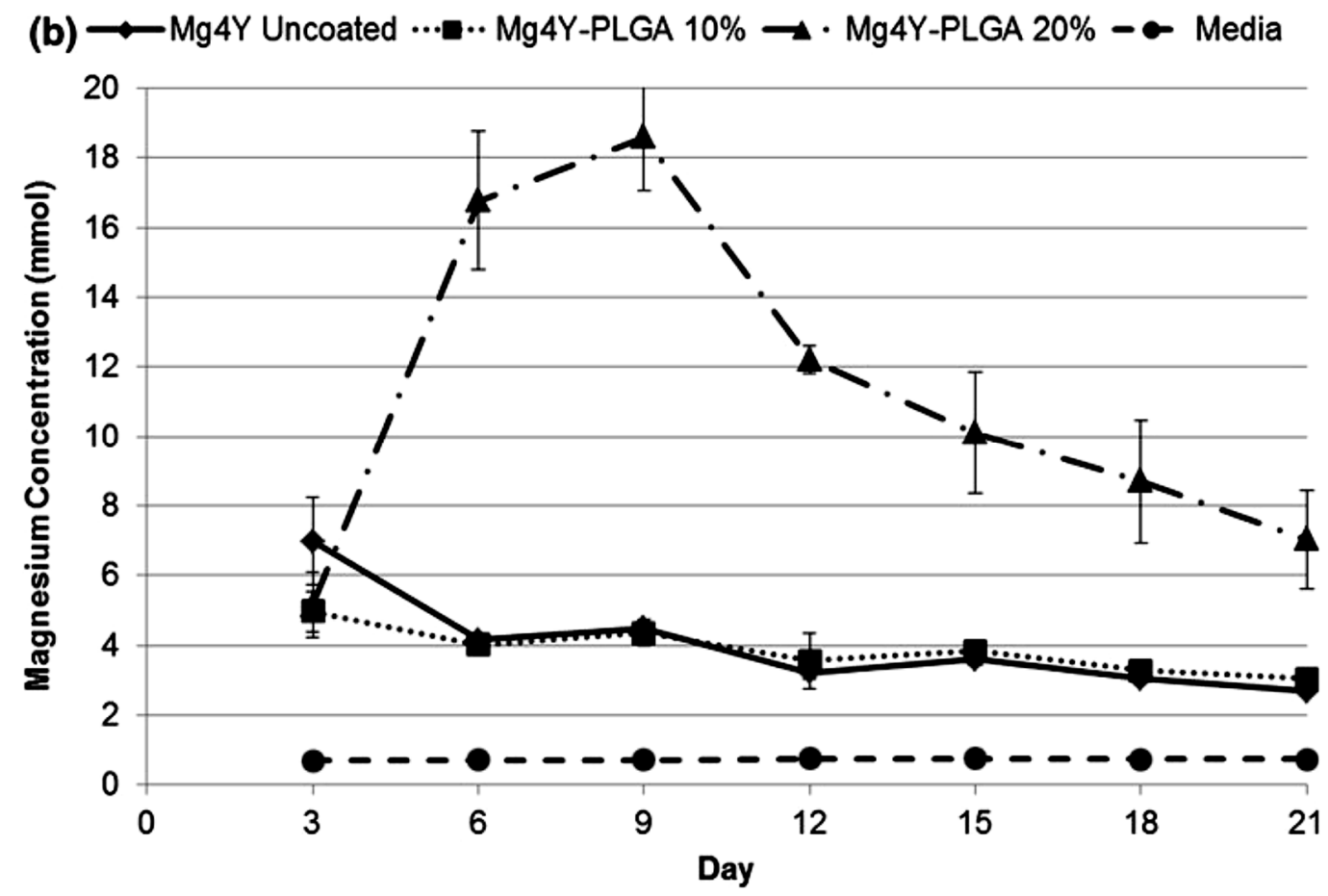

Figure 4. The magnesium ion concentration of the poly (lactic-co-glycolic acid) polymer-coated (a) AZ21 and (b) Mg4Y alloy substrates in DMEM at various days of immersion. Obtained from [65], with permission from Thin Solid Films, Elsevier, 2018.

Shi et al. [68] reported that the adhesion of PLA coatings on the magnesium alloy can be significantly improved by a surface pre-treatment using micro-arc oxidation (MAO). The adhesion strength test of a PLA/MAO coating on the AZ31 magnesium alloy showed that MAO improved the bonding of the PLA film to the MgO layer. The PLA/MAO coating significantly improved the corrosion resistance of AZ31 alloys. However, Li et al. [67] reported that MAO pre-treatment can potentially facilitate the development of a porous coating with cracks. Thus, they [67] developed a duplex coating composed of a MAO (an alkaline silicate-flouride-based electrolyte) inner layer and a polycaprolactone (PCL) top biodegradable layer. SEM images revealed the formation of micropores $(\sim 1 \mu \mathrm{m})$ on the just MAO-treated surface (Figure $5 \mathrm{a})$. However, the coating prepared with $4 \mathrm{wt} \%$ of PCL produced a uniform polymer layer with much fewer micropores $(0.5 \mu \mathrm{m})$ over the crater-like MAO surface (Figure 5c). Increasing the PCL concentration to $7 \%$ formed a uniform and pore-free coating with complete coverage over the MOA-coated Mg (Figure 5e). The cross-sectional view showed that the thickness of the coating developed with 7\% PCL was 3 times higher than that of the MOA treatment. Potentiodynamic polarization test results indicated that the coating developed with 7\% PCL provided the best corrosion resistance in Hanks' solution. Tian et al. [69] also reported that a duplex coating, composed of PCL and plasma electrolytic oxidization PEO layers, significantly improved the corrosion resistance of an AZ31 magnesium alloy. A further modification of the PEO/PCL coating with polydopamine (PDAM) showed no obvious improvement in corrosion resistance, resistance to hydrogen evolution, and cytocompatibility. However, the surface became more suitable for cell adhesion after the PDAM treatment [69]. 

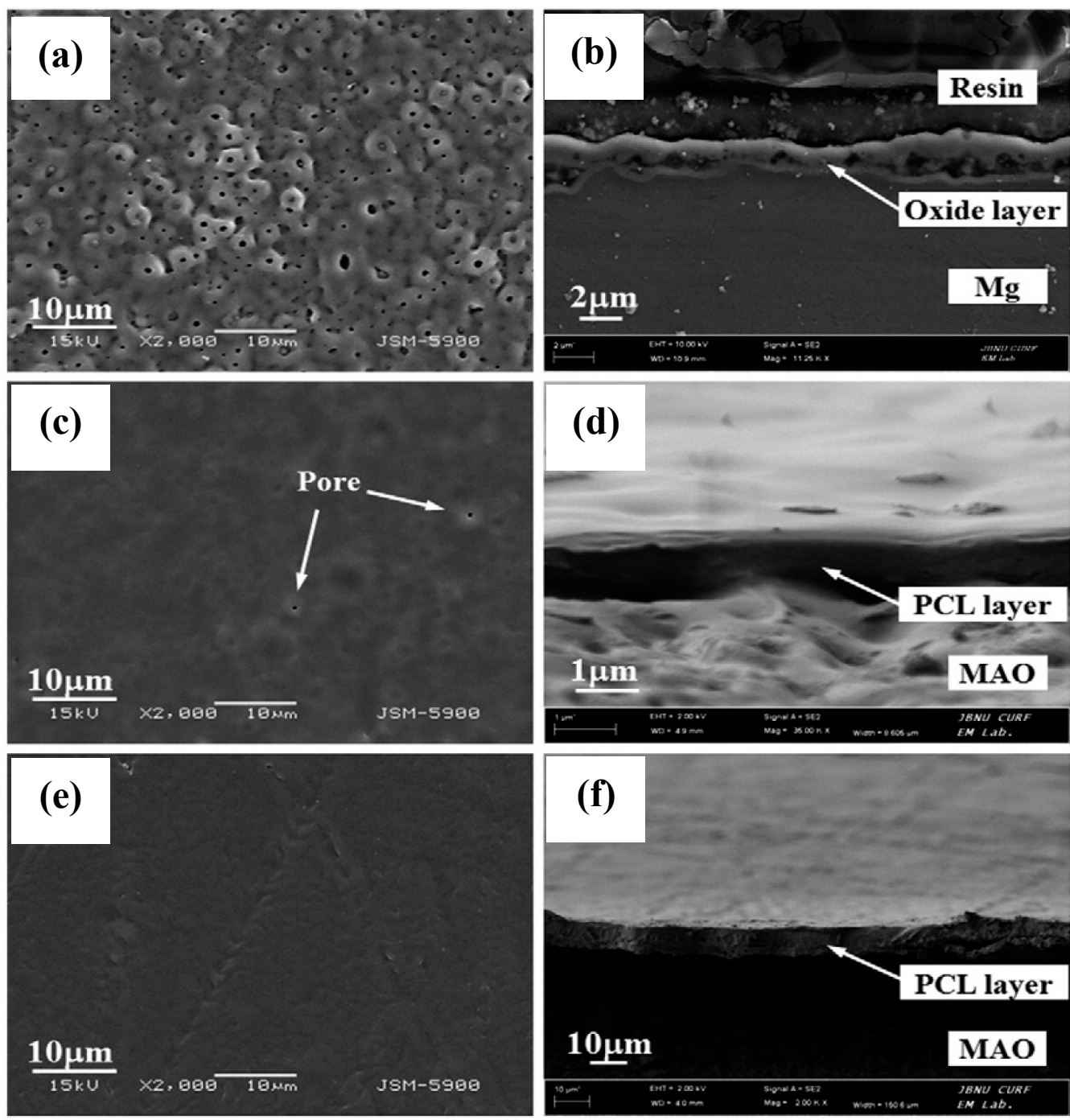

Figure 5. Surface morphology $(\mathbf{a}, \mathbf{c}, \mathbf{e})$ and cross-section images $(\mathbf{b}, \mathbf{d}, \mathbf{f})$ of the $(\mathbf{a}, \mathbf{b})$ micro-arc oxidation (MAO)-treated, (c,d) MAO-4\% PCL duplex-coated, and (e,f) MAO-7\% PCL duplex-coated magnesium. Obtained from [67], with permission from Thin Solid Films, Elsevier, 2018.

Hanas et al. [70] deposited a PCL-nanofibrous layer on an AZ31 magnesium alloy using an electrospinning technique. Randomly aligned and uniform nanofibers with an average diameter of $400 \mathrm{~nm}$ were deposited on the alloy's surface due to the PCL coating. They concluded that the PCL coating reduced the rate of increase of $\mathrm{pH}$ and the rate of $\mathrm{H}_{2}$ evolution, facilitated the deposition of $\mathrm{Ca}-\mathrm{P}$, improved the biomineralization, and inhibited pitting corrosion during immersion in supersaturated simulated body fluid. $\mathrm{Xi}$ et al. [71] synthesized a composite coating containing a hyperbranched polyphenylene sulphide (HPPS), polycaprolactone (PCL), and zinc oxide (ZnO) with a view to decreasing the corrosion rate of AZ91 alloy in SBF [71]. While the PCL coatings formed an interconnected pore network, the addition of $\mathrm{ZnO}$ and HPPS significantly reduced the porosity and improved the uniformity of the resultant coating. The HPPS/PCL/ZnO composite coating possessed superior corrosion resistance as compared to PCL and PCL/ZnO coatings. In another study, polycaprolactone (PCL) and zinc-oxide nanoparticle ( $\mathrm{ZnO} \mathrm{NP}$ ) composite coatings were deposited on AZ31 by electrospinning, which also improved the corrosion resistance of this alloy in simulated body fluid [72]. Surface pre-treatments, such as micro-arc oxidation and plasma electrolytic oxidation, and the inclusion of metal particles, such as $\mathrm{ZnO}$ and $\mathrm{TiO}$, seem to improve the uniformity and adhesion 
and reduce the porosity of the polymeric coatings, which results in a significant improvement in the corrosion resistance of magnesium implants.

\subsection{Biodegradable Silane Coatings}

Silane coatings have been widely used to improve the corrosion resistance of various magnesium alloys in different corrosive environments. A few different types of silanes have been considered as biocompatible [73] and have been reported to improve the corrosion resistance of a few magnesium implants. Jiang et al. [74] have reported that an amine silane treatment on a bioglass fibre had little negative effect on the biological response of these fibres. Muller et al. [75] reported that a collagen and amino silane coating synthesized on stainless steel facilitated cell proliferation and adhesion to the substrate. Additionally, Glycidoxypropyltrimethoxy silane has been routinely used as a bioactive and biocompatible binder and precursor for the synthesis of porous gelatine-siloxane hybrids for bone tissues [76,77].

Liu et al. [78] used a two-step duplex coating on a hydroxide pre-treated AZ31 magnesium alloy. In the first step, they synthesized a bistriethoxysilylethane (BTSE) coating, and, in the second step, they synthesized a 3-aminopropyltrimethoxysialne ( $\gamma$-APS) coating on the BTSE-coated AZ31 substrate. To further improve the bioactivity of the BTSE/ $\gamma$-APS-coated AZ31 alloy's surface, they attached heparin on the coated surface. They reported that, even though the BTSE/ $\gamma$-APS coating significantly improved the corrosion resistance of the AZ31 substrate, the inclusion of heparin deteriorated the corrosion resistance of the coated implant (Figure 6).

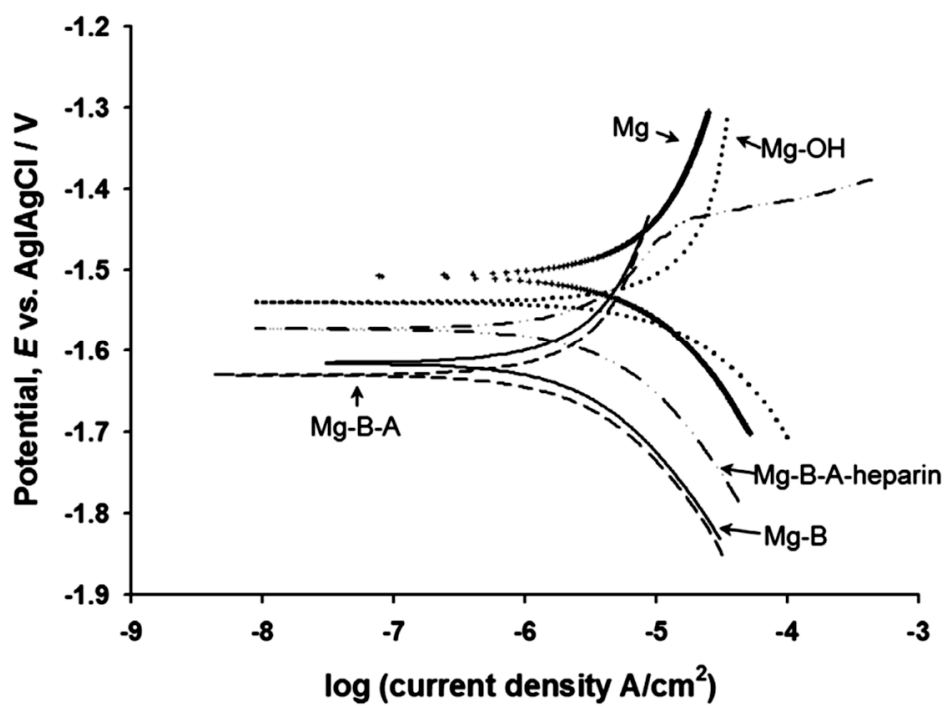

Figure 6. The potentiodynamic polarization of the uncoated, hydroxide pre-treated, BTSE-coated, $\gamma$-APS-coated, BTSE $/ \gamma$-APS-coated, and BTSE $/ \gamma$-APS/heparin-coated AZ31 alloy in simulated body fluid. Obtained from [78], with permission from Acta Biomaterialia, Elsevier, 2018.

Gaur et al. [79] synthesized a series of silane mixture coatings using different ratios of diethylphosphateoethyltriethoxysilane (DEPETES) and bis-[3-(triethoxysilyl) propyl]tetrasulfide (BTESPT). They reported that a coating developed by mixing DEPETES and BTESPT in a ratio of 1:4 significantly improved the corrosion resistance of a $\mathrm{Mg}-6 \mathrm{Zn}-\mathrm{Ca}$ alloy and delayed the corrosion of this alloy for the entire duration of immersion $(175 \mathrm{~h})$ in modified simulated body fluid. In a subsequent study, Gaur et al. [80] reported that glycidoxypropyl-trimethoxysilane, when mixed with methyltriethoxy-silane in a ratio of 3:1, significantly improved the corrosion resistance of a $\mathrm{Mg}-6 \mathrm{Zn}-\mathrm{Ca}$ alloy in modified simulated body fluid.

Cordoba et al. [81] synthesized a glycidoxypropyl-trimethoxysilane coating modified with titanium iso-propoxide that significantly improved the corrosion resistance of AZ31 alloy during 
immersion in simulated body fluid (SBF) for 7 weeks. However, when applied to ZE41 alloy, this coating showed limited corrosion protection after 7 weeks of immersion in SBF. Al-Saadi et al. [82] impregnated glycidoxypropyl-trimethoxysilane with hexagonal boron nitride and applied this coating to WZ21 alloy. They reported that this biocompatible coating significantly improved the corrosion resistance of WZ21 alloy in simulated body fluid. Most of the reports [78-81] related to silane coatings on magnesium implants concluded that the hydrophobic nature of silane inhibited the ingress of corrosive ions to the metal substrate's surface, which explains the significantly improved corrosion resistance of magnesium implants due to the silane coatings.

\subsection{Biodegradable Calcium Phosphate Coatings}

Calcium (Ca) and phosphorous $(\mathrm{P})$ are the two major elements present in bone minerals $[83,84]$. Thus, the surface modification of magnesium alloys with $\mathrm{Ca}-\mathrm{P}$ coatings can potentially improve the biocompatibility of, and facilitate osteointegration around, the coated implants [84]. Song et al. [84] electrodeposited three different types of $\mathrm{Ca}-\mathrm{P}$ coatings, brushite $\left(\mathrm{CaHPO}_{4} \cdot 2 \mathrm{H}_{2} \mathrm{O}\right)$, hydroxyapatite $\left(\mathrm{Ca}_{10}\left(\mathrm{PO}_{4}\right)_{6}(\mathrm{OH})_{2}\right)$, and fluoridated hydroxyapatite $\left(\mathrm{Ca}_{5}\left(\mathrm{PO}_{4}\right)_{3}(\mathrm{OH})_{1-x} \mathrm{~F}_{\mathrm{x}}\right)$, on a $\mathrm{Mg}-\mathrm{Zn}$ alloy. The morphologies of the three coatings and the cross-section of the fluoridated hydroxyapatite-coated substrate are shown in Figure 7. Even though all three coatings improved the corrosion resistance of the magnesium alloy, the brushite-coated specimen showed delayed bone-like apatite formation as compared to the hydroxyapatite- and fluoridated-hydroxyapatite-coated specimens, both of which promoted the nucleation of osteoconductive minerals (apatite or $\beta$-TCP) for one month. Since the hydroxyapatite coating synthesized through the alkali heat treatment of brushite was fragile and less stable, they concluded that the fluoridated hydroxyapatite coating was superior for improving the bioactivity and corrosion resistance of the $\mathrm{Mg}-\mathrm{Zn}$ alloy substrates.
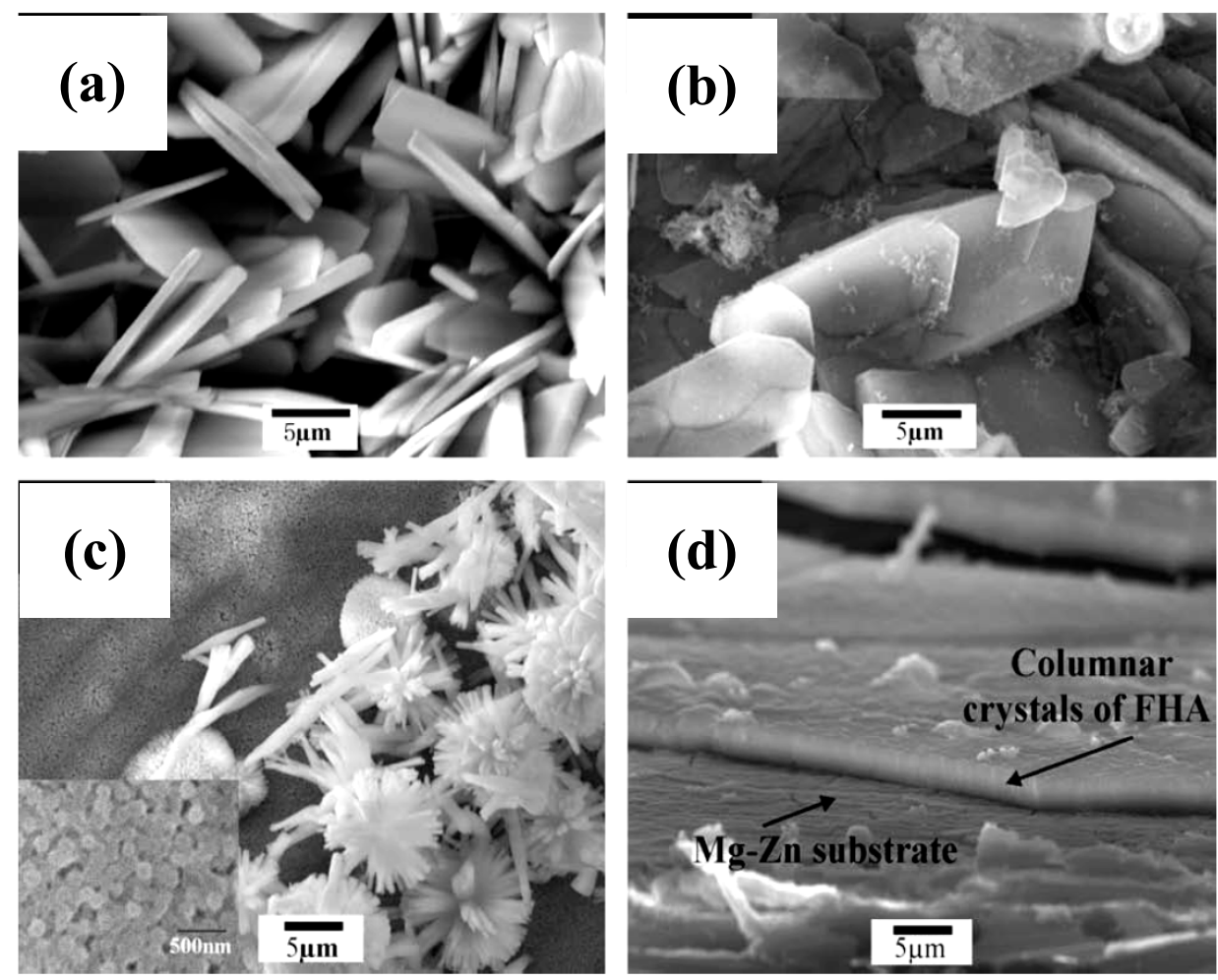

Figure 7. Surface morphologies of: (a) brushite-coated, (b) hydroxyapatite-coated, and (c) fluoridated-hydroxyapatite-coated $\mathrm{Mg}-\mathrm{Zn}$ alloy substrates. (d) Cross-sectional view of the fluoridated-hydroxyapatite-coated specimen. Obtained from [84], with permission from Acta Biomaterialia, Elsevier, 2018. 
Liu et al. [85] used a hydrothermal method to synthesize nanostructured dibasic calcium phosphate, which significantly improved the corrosion resistance of an AZ31B magnesium alloy. Jafari et al. [86] has also reported improvement in the corrosion resistance of an AZ91D alloy due to a Ca-P coating. Kannan et al. [87] employed an innovative pulse-potential technique to synthesize a $\mathrm{Ca}-\mathrm{P}$ coating on an AZ91D alloy. There was a distinct morphological difference between the Ca-P coating developed using a constant potential and the pulse potential (Figure 8). The coating synthesized using the pulse potential showed higher corrosion resistance as compared to that synthesized using a constant potential. Wang et al. [88] had also used a pulsed electrodeposition technique to synthesize a calcium-deficient hydroxyapatite coating on a $\mathrm{Mg}-\mathrm{Zn}-\mathrm{Ca}$ alloy, which provided an order of magnitude improvement in corrosion resistance to the uncoated alloy. Meng et al. [89] used pulse electrodeposition to synthesize a fluorine-doped hydroxyapatite coating, which significantly improved the corrosion resistance of a Mg-Zn-Ca alloy. Additionally, they had reported that the nanophase and the high surface area of the fluorine-doped hydroxyapatite coating facilitated the precipitation of $\mathrm{Mg}^{2+}, \mathrm{Ca}^{2+}$, and $\mathrm{PO}_{4}{ }^{3-}$ ions.
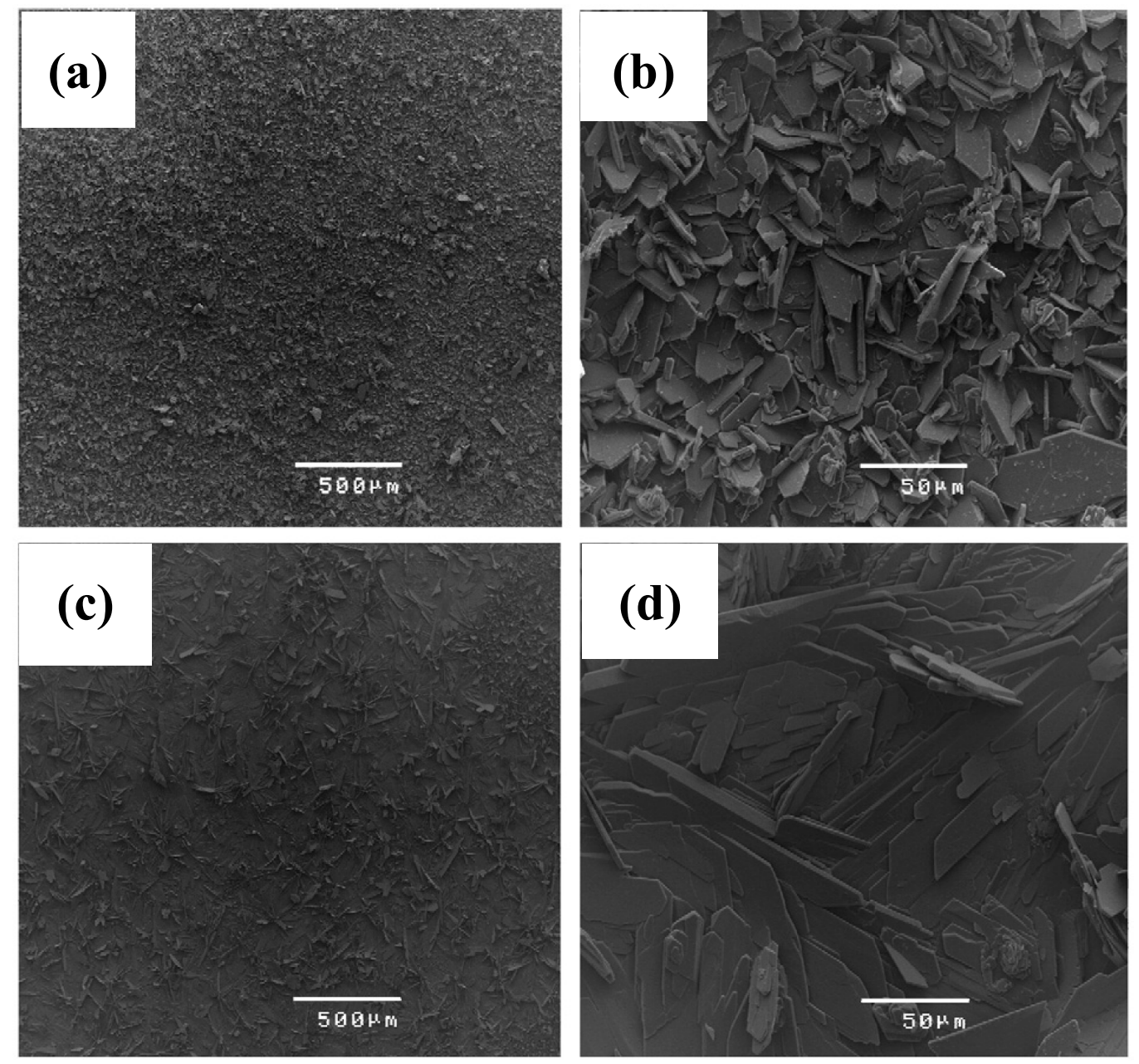

Figure 8. Surface morphologies of the Ca-P coating synthesized using $(\mathbf{a}, \mathbf{c})$ constant potential and $(\mathbf{b}, \mathbf{d})$ pulse potential techniques. Obtained from [87], with permission from Materials Letters, Elsevier, 2018.

Surmeneva et al. [90] used radio frequency magnetron scattering to deposit a thin film (550-750 nm thick) of hydroxyapatite on a Mg-Ca alloy. Potentiodynamic polarization tests suggested that this coating was able to suppress the cathodic reactions; however, the anodic current densities of the coated alloy were similar to that of the uncoated one. A radio frequency magnetron technique was also used by Mukhametkaliyev et al. [91] to synthesize a dense nanostructured hydroxyapatite coating with low 
porosity on an AZ91 alloy. This nanostructured coating significantly improved the corrosion resistance of the alloy as well as improved its bioactivity via apatite formation. The post-corrosion morphologies of the uncoated and coated specimens are shown in Figure 9.
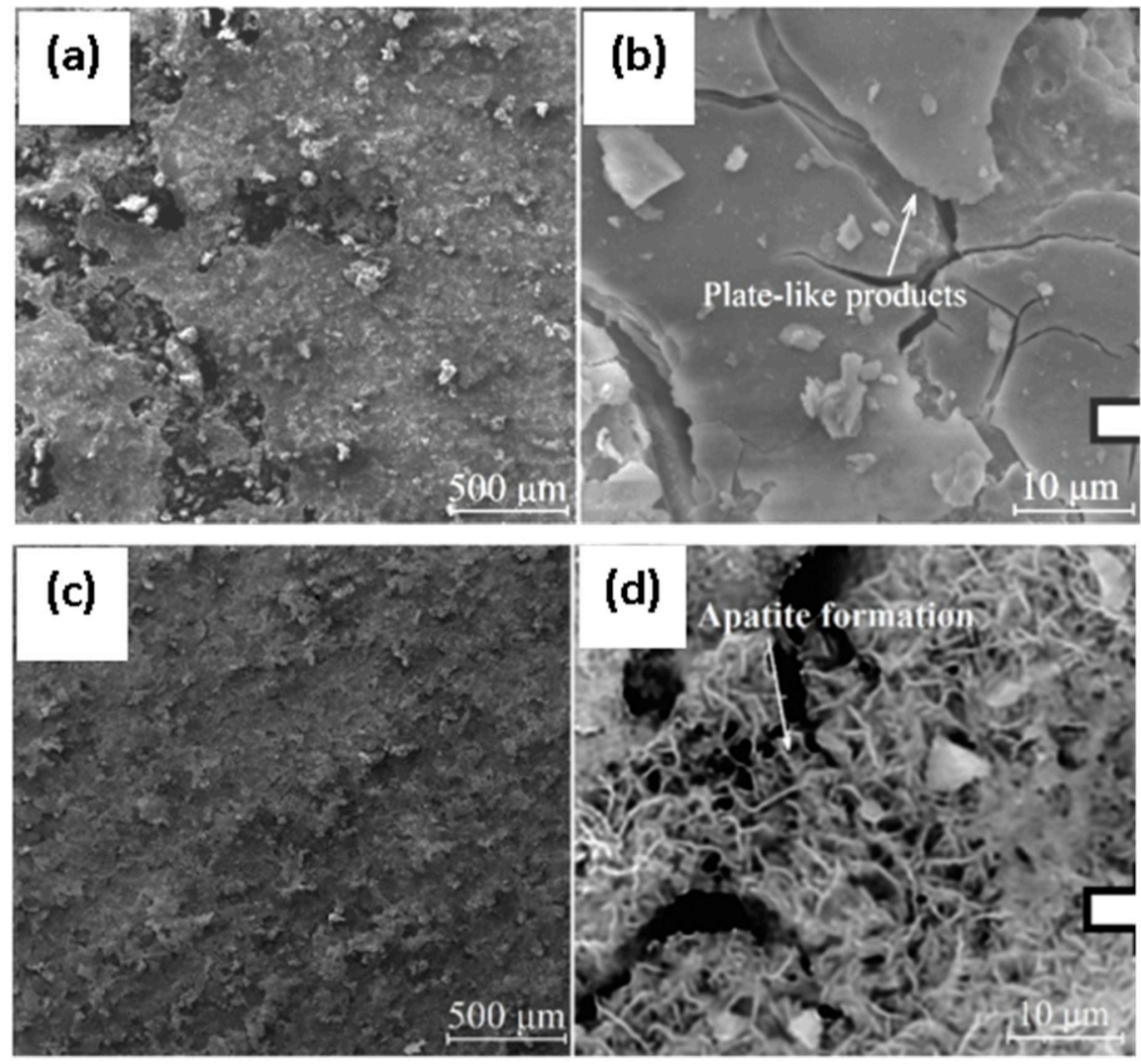

Figure 9. Post-corrosion morphologies of the $(\mathbf{a}, \mathbf{b})$ uncoated and $(\mathbf{c}, \mathbf{d})$ nanostructured-hydroxyapatitecoated alloy substrate after 7 days of immersion in simulated body fluid. Obtained from [91], with permission from Materials Science and engineering C, Elsevier, 2018.

Ren et al. [92] have reported an innovative microwave-assisted technique to synthesize a dense and uniform calcium-deficient hydroxyapatite coating on an AZ31 alloy. The coating significantly improved the corrosion resistance of the alloy in simulated body fluid and promoted the formation of a dense apatite layer after 7 days of immersion. Additionally, a cell culture study revealed that this coating stimulated cell proliferation during 5 days of incubation. Abdal-hay et al. [93] synthesized a composite coating using nanostructured hydroxyapatite and poly( $\varepsilon$-caprolactone). The poly( $\varepsilon$-caprolactone) coating with and without nanostructured hydroxyapatite improved the corrosion resistance; however,

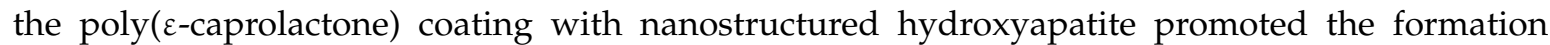
and uniform distribution of apatite particles. Subsequently, Abdal-hay et al. [94] synthesized a hydroxyapatite-doped poly(lactic acid) coating on an AZ31B alloy. They reported that the addition of hydroxyapatite improved the hydrophobicity of the coating. This coating also improved the corrosion resistance and promoted apatite formation on the AZ31B alloy. Zomorodian et al. [95] synthesized a composite coating using polycaprolactone, nanostructured hydroxyapatite, and ceplalexin. They concluded that, even though the polycaprolactone coating by itself provides corrosion protection to AZ31 alloy in Hanks' solution, the addition of ceplalexin and nanostructured hydroxyapatite to the polycaprolactone coating decreased the corrosion protection offered by the coating. 


\subsection{Graphene-Derivative-Based Coatings}

Recently, graphene and graphene derivatives have attracted significant attention as coatings for implants. These coatings have been reported to facilitate adhesion and the proliferation of the human-osteoblast-like cell line, and show potential to facilitate the differentiation of mesenchymal stromal cells into the osteoblast lineage [96-98]. Kim et al. [99] converted free-standing graphene/calcium carbonate $\left(\mathrm{CaCO}_{3}\right)$ films into graphene/hydroxyapatite composites after incubating them in simulated body fluid for 4 days. Lahiri et al. [100] have reported that low concentrations of graphene fillers can improve the biocompatibility to bone cells. In one of the first reports, Li et al. [101] reported a higher open-circuit potential (Figure 10a) and lower anodic and cathodic current densities (Figure 10b) due to graphene oxide/hydroxyapatite composite coatings, and found a significant improvement in the corrosion resistance of a titanium substrate due to these coatings. This concept was subsequently extended to magnesium implants.
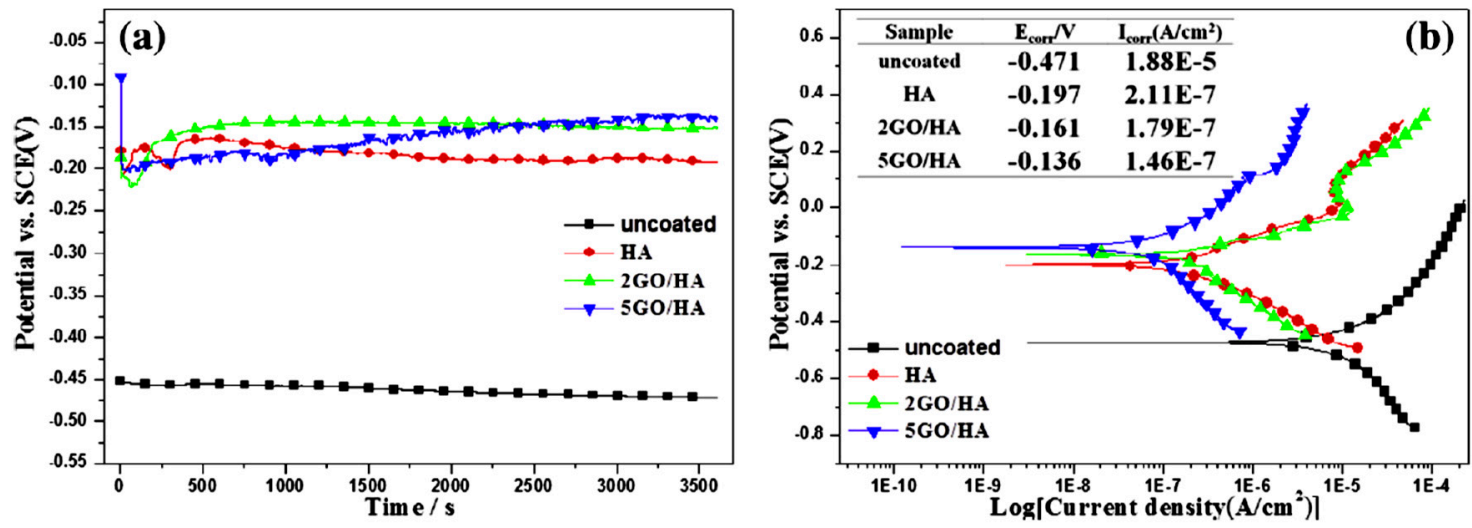

Figure 10. (a) open circuit voltage versus time and (b) potentiodynamic polarization plots of the uncoated, hydroxyapatite-coated, and graphene oxide (GO)/hydroxyapatite-coated titanium substrate. Obtained from [101], with permission from Carbon, Elsevier, 2018.

Gao et al. [102] synthesized a 34- $\mu \mathrm{m}$ thick graphene oxide/hydroxyapatite coating on an AZ91 alloy. The alloy substrate was, at first, dip-coated by graphene oxide (GO), and was then exposed to simulated body fluid, which facilitated the biomimetic mineralization of hydroxyapatite on the GO coating. They reported that graphene oxide promoted the nucleation and subsequent growth of a dense and uniform hydroxyapatite layer. Figure 11 shows the surface morphologies of graphene oxide/hydroxyapatite coatings as a function of solution $\mathrm{pH}$ and duration of immersion in modified simulated body fluid. These coatings were reported to significantly improve the corrosion resistance of the magnesium alloy substrates in simulated body fluid. Santos et al. [103] synthesized an ultrathin $(1 \mu \mathrm{m})$ graphene oxide/hydroxyapatite nanoparticle coating on an ultra-high purity magnesium substrate. The surface morphology and the cross-section of this coating are shown in Figure 12. However, the coating provided little corrosion protection to the magnesium alloy substrate. 

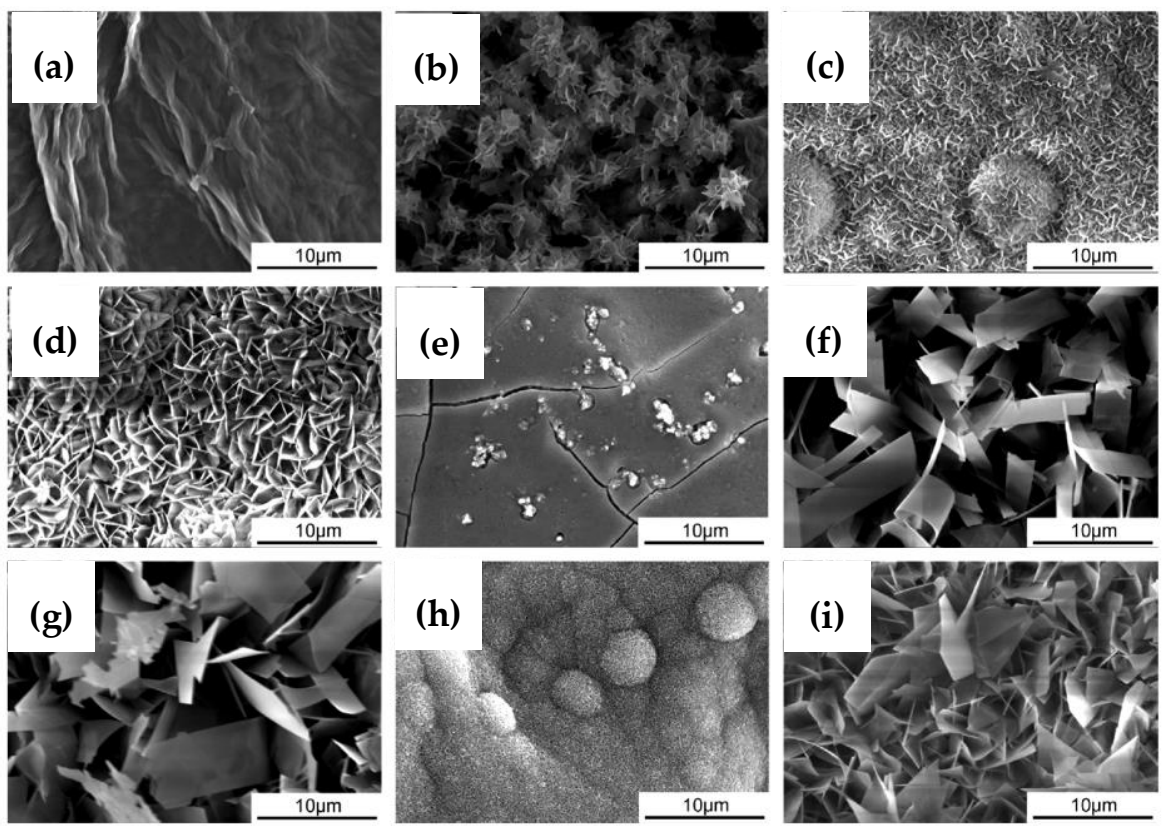

Figure 11. Surface morphologies of (a) the graphene oxide coating on AZ91. (b-d) the graphene oxide/hydroxyapatite coating with a growth time of 6 h, 1 day, and 2 days, respectively, at a pH of 6.65, (e-g) the hydroxyapatite-only coating with a growth time of 6 h, 1 day, and 2 days, respectively, at a $\mathrm{pH}$ of 6.65. A graphene oxide/hydroxyapatite coating grown for 2 days at a pH of (h) 6.4 and (i) 6.9. Obtained from [102], with permission from Materials Letters, Elsevier, 2018.
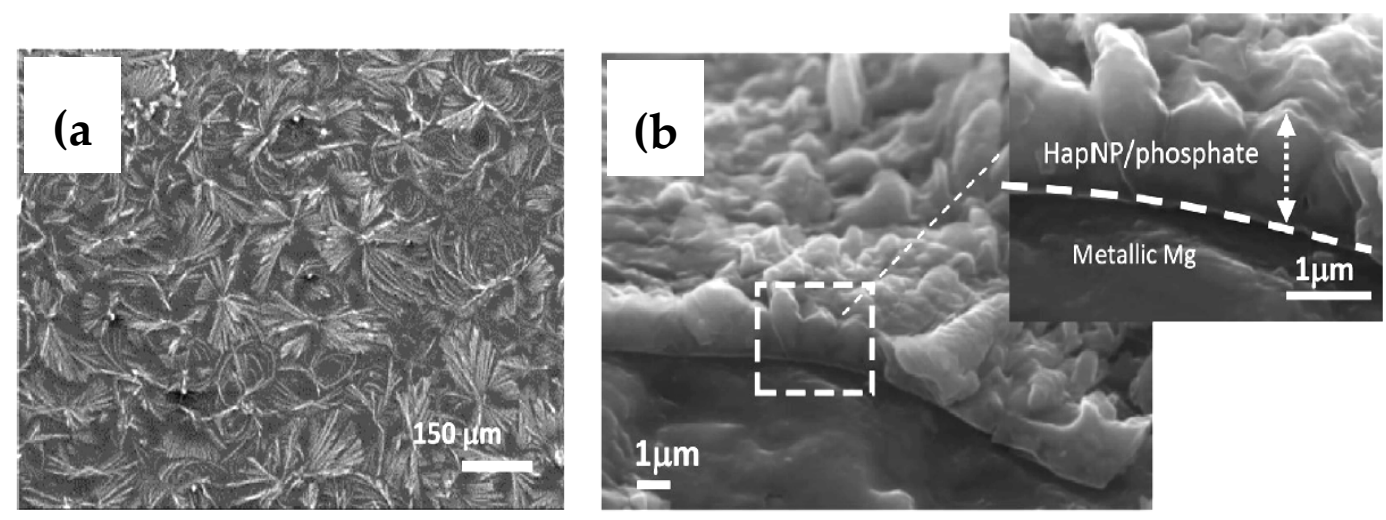

Figure 12. The (a) surface morphology and (b) cross section of a graphene oxide/hydroxyapatite nanoparticle coating on a high-purity magnesium substrate. Obtained from [103], with permission from Applied Surface Science, Elsevier, 2018.

\section{Conclusions}

The ability of biocompatible magnesium and its alloys to easily corrode in human body fluid without generating any toxic products makes them one of the most suitable candidate materials for biodegradable temporary implants. However, the very high corrosion rate limits their use as an implant as it may potentially degrade even before the healing has been completed. There are a few different approaches to improve the corrosion resistance of magnesium implants. Various strategies, including alloying, surface modification using energetic radiation, and conversion coatings, have been employed to improve the corrosion resistance of various magnesium alloys. Among these strategies, conversion coatings have been the most widely used approach for a variety of magnesium alloys. Biocompatibility and good barrier properties are the key criteria that a coating must satisfy in order to be used on implants. Various different types of coatings, including polymeric coatings, calcium-phosphate 
coatings, and graphene coatings have significantly improved the corrosion resistance of magnesium and its alloys. However, one of the major drawbacks in the reports on the corrosion behavior and coatings of magnesium implants has been the lack of data under in-vivo conditions. Even though there has been a consensus in the literature about the major differences in in-vivo and in-vitro conditions, little has been reported on the corrosion behavior of the implants and/or the performance of the coating synthesized on the implants. The prospects of magnesium alloys as temporary implants will significantly depend on the in-vivo performance evaluation of these various biodegradable coating systems.

Author Contributions: Conceptualization, writing, editing, and review, P.C.B.; writing, S.A.-S.; reviewing and writing, R.S.; reviewing and writing, L.C.; reviewing and writing, S.E.H.

Funding: This research received no external funding.

Conflicts of Interest: The authors declare no conflicts of interest.

\section{References}

1. Mushahary, D. Surface Functionalisation of Magnesium Alloys for Use as Bio-Implants; Institute for Frontier Materials, Deakin University: Geelong, Australia, 2014.

2. Niinomi, M. Recent metallic materials for biomedical applications. Metall. Mater. Trans. A 2002, $33,477$. [CrossRef]

3. Williams, D.F. Corrosion of Implant Materials. Annu. Rev. Mater. Sci. 1976, 6, 237-266. [CrossRef]

4. Nielsen, K. Corrosion of metallic implants. Br. Corros. J. 1987, 22, 272-278. [CrossRef]

5. Niinomi, M. Metallic biomaterials. J. Artif. Organs 2008, 11, 105. [CrossRef] [PubMed]

6. Witte, F. The history of biodegradable magnesium implants: A review. Acta Biomater. 2011, 6, 1680-1692. [CrossRef] [PubMed]

7. Wang, J.Y.; Wicklund, B.H.; Gustilo, R.B.; Tsukayama, D.T. Titanium, chromium and cobalt ions modulate the release of bone-associated cytokines by human monocytes/macrophages in vitro. Biomaterials 1996, 17, 2233-2240. [CrossRef]

8. Erne, P.; Schier, M.; Resink, T.J. The Road to Bioabsorbable Stents: Reaching Clinical Reality? CardioVasc. Int. Radiol. 2006, 29, 11-16. [CrossRef]

9. Staiger, M.P.; Pietak, A.M.; Huadmai, J.; Dias, G. Magnesium and its alloys as orthopedic biomaterials: A review. Biomaterials 2006, 27, 1728-1734. [CrossRef] [PubMed]

10. Zeng, R.; Dietzel, W.; Witte, F.; Hort, N.; Blawert, C. Progress and Challenge for Magnesium Alloys as Biomaterials. Adv. Eng. Mater. 2008, 10, B3-B14. [CrossRef]

11. Zberg, B.; Uggowitzer, P.J.; Loffler, J.F. MgZnCa glasses without clinically observable hydrogen evolution for biodegradable implants. Nat. Mater. 2009, 8, 887-891. [CrossRef]

12. Walker, J.; Shadanbaz, S.; Woodfield, T.B.F.; Staiger, M.P.; Dias, G.J. Magnesium biomaterials for orthopedic application: A review from a biological perspective. J. Biomed. Mater. Res. Part B Appl. Biomater. 2014, 102, 1316-1331. [CrossRef] [PubMed]

13. Song, G.-L. Corrosion of Magnesium Alloys; Woodhead Publishing: Cambridge, UK, 2011.

14. Böstman, O.M. Osteolytic changes accompanying degradation of absorbable fracture fixation implants. J. Bone Jt. Surg. 1991, 73, 679-682. [CrossRef]

15. Cheung, H.-Y.; Lau, K.-T.; Lu, T.-P.; Hui, D. A critical review on polymer-based bio-engineered materials for scaffold development. Compos. Part B Eng. 2007, 38, 291-300. [CrossRef]

16. Neves, N.M.; Kouyumdzhiev, A.; Reis, R.L. The morphology, mechanical properties and ageing behavior of porous injection molded starch-based blends for tissue engineering scaffolding. Mater. Sci. Eng. C 2005, 25, 195-200. [CrossRef]

17. Wong, P.-C.; Tsai, P.-H.; Li, T.-H.; Cheng, C.-K.; Jang, J.S.C.; Huang, J.C. Degradation behavior and mechanical strength of $\mathrm{Mg}-\mathrm{Zn}$-Ca bulk metallic glass composites with Ti particles as biodegradable materials. J. Alloys Compd. 2017, 699, 914-920. [CrossRef]

18. Song, Y.W.; Shan, D.Y.; Han, E.H. Electrodeposition of hydroxyapatite coating on AZ91D magnesium alloy for biomaterial application. Mater. Lett. 2008, 62, 3276-3279. [CrossRef] 
19. Hänzi, A.C.; Gerber, I.; Schinhammer, M.; Löffler, J.F.; Uggowitzer, P.J. On the in vitro and in vivo degradation performance and biological response of new biodegradable $\mathrm{Mg}-\mathrm{Y}-\mathrm{Zn}$ alloys. Acta Biomater. 2010, 6, 1824-1833. [CrossRef] [PubMed]

20. Jacobs, J.J.M.D.; Hallab, N.J.P.; Skipor, A.K.M.S.; Urban, R.M.A.S. Metal Degradation Products: A Cause for Concern in Metal-Metal Bearings? Clin. Orthop. Relat. Res. 2003, 417, 139-147.

21. Wolf, F.; Cittadini, A. Chemistry and Biochemistry of Magnesium. Mol. Asp. Med. 2003, 24, 3-9. [CrossRef]

22. Harandi, S.E.; Banerjee, P.C.; Easton, C.D.; Singh Raman, R.K. Influence of bovine serum albumin in Hanks' solution on the corrosion and stress corrosion cracking of a magnesium alloy. Mater. Sci. Eng. C 2017, 80, 335-345. [CrossRef]

23. Grimm, M.J. Selection of Materials for Biomedical Applications. In Handbook of Materials Selection; John Wiley \& Sons, Inc.: Hoboken, NJ, USA, 2007. [CrossRef]

24. Witte, F.; Hort, N.; Vogt, C.; Cohen, S.; Kainer, K.U.; Willumeit, R.; Feyerabend, F. Degradable biomaterials based on magnesium corrosion. Curr. Opin. Solid State Mater. Sci. 2008, 12, 63-72. [CrossRef]

25. Witte, F. Reprint of: The history of biodegradable magnesium implants: A review. Acta Biomater. 2015, 23, S28-S40. [CrossRef] [PubMed]

26. Witte, F.; Fischer, J.; Nellesen, J.; Crostack, H.-A.; Kaese, V.; Pisch, A.; Beckmann, F.; Windhagen, H. In vitro and in vivo corrosion measurements of magnesium alloys. Biomaterials 2006, 27, 1013-1018. [CrossRef] [PubMed]

27. McBRIDE, E.D. Absorbable metal in bone surgery: A further report on the use of magnesium alloys. J. Am. Med. Assoc. 1938, 111, 2464-2467. [CrossRef]

28. Witte, F.; Kaese, V.; Haferkamp, H.; Switzer, E.; Meyer-Lindenberg, A.; Wirth, C.J.; Windhagen, H. In vivo corrosion of four magnesium alloys and the associated bone response. Biomaterials 2005, 26, 3557-3563. [CrossRef] [PubMed]

29. Friedrich, H.E.; Mordike, B.L. Magnesium Technology; Springer: Berlin/Heidelberg, Germany, 2006. [CrossRef]

30. Avedesian, M.M.; Baker, H. (Eds.) Magnesium and Magnesium Alloys, ASM Speciality Handbook; ASM International: Materials Park, OH, USA, 1999.

31. Choudhary, L.; Singh Raman, R.K. Magnesium alloys as body implants: Fracture mechanism under dynamic and static loadings in a physiological environment. Acta Biomater. 2012, 8, 916-923. [CrossRef] [PubMed]

32. Raman, R.K.S.; Choudhary, L. Cracking of magnesium-based biodegradable implant alloys under the combined action of stress and corrosive body fluid: A review. Emerg. Mater. Res. 2013, 2, 219-228. [CrossRef]

33. Kannan, M.B.; Raman, R.K.S. In vitro degradation and mechanical integrity of calcium-containing magnesium alloys in modified-simulated body fluid. Biomaterials 2008, 29, 2306-2314. [CrossRef] [PubMed]

34. Bobby Kannan, M.; Singh Raman, R.K.; Witte, F.; Blawert, C.; Dietzel, W. Influence of circumferential notch and fatigue crack on the mechanical integrity of biodegradable magnesium-based alloy in simulated body fluid. J. Biomed. Mater. Res. Part B Appl. Biomater. 2011, 96, 303-309. [CrossRef] [PubMed]

35. Bobby Kannan, M.; Singh Raman, R.K. Evaluating the stress corrosion cracking susceptibility of $\mathrm{Mg}-\mathrm{Al}-\mathrm{Zn}$ alloy in modified-simulated body fluid for orthopaedic implant application. Scr. Mater. 2008, 59, 175-178. [CrossRef]

36. Song, G. Control of biodegradation of biocompatable magnesium alloys. Corros. Sci. 2007, 49, $1696-1701$. [CrossRef]

37. Song, G.L.; Atren, A. Corrosion Mechanisms of Magnesium Alloys. Adv. Eng. Mater. 1999, 1, 11-33. [CrossRef]

38. Zainal Abidin, N.I.; Atrens, A.D.; Martin, D.; Atrens, A. Corrosion of high purity Mg, Mg2Zn0.2Mn, ZE41 and AZ91 in Hank's solution at $37^{\circ} \mathrm{C}$. Corros. Sci. 2011, 53, 3542-3556. [CrossRef]

39. Ma, E.; Xu, J. The glass window of opportunities. Nat. Mater. 2009, 8, 855. [CrossRef]

40. Atrens, A.; Liu, M.; Zainal Abidin, N.I. Corrosion mechanism applicable to biodegradable magnesium implants. Mater. Sci. Eng. B 2011, 176, 1609-1636. [CrossRef]

41. Williams, D. New interest in magnesium. Med. Device Technol. 2006, 17, 9-10.

42. Song, G.; Atrens, A.; John, D.S.; Wu, X.; Nairn, J. The anodic dissolution of magnesium in chloride and sulphate solutions. Corros. Sci. 1997, 39, 1981-2004. [CrossRef]

43. Poinern, G.E.J.; Brundavanam, S.; Fawcett, D. Biomedical Magnesium Alloys: A Review of Material Properties, Surface Modifications and Potential as a Biodegradable Orthopaedic Implant. Am. J. Biomed. Eng. 2012, 2, 218-240. [CrossRef] 
44. Kraus, T.; Fischerauer, S.F.; Hänzi, A.C.; Uggowitzer, P.J.; Löffler, J.F.; Weinberg, A.M. Magnesium alloys for temporary implants in osteosynthesis: In vivo studies of their degradation and interaction with bone. Acta Biomater. 2012, 8, 1230-1238. [CrossRef] [PubMed]

45. Kirkland, N.T.; Lespagnol, J.; Birbilis, N.; Staiger, M.P. A survey of bio-corrosion rates of magnesium alloys. Corros. Sci. 2010, 52, 287-291. [CrossRef]

46. Xin, Y.; Liu, C.; Zhang, X.; Tang, G.; Tian, X.; Chu, P.K. Corrosion behavior of biomedical AZ91 magnesium alloy in simulated body fluids. J. Mater. Res. 2007, 22, 2004-2011. [CrossRef]

47. Rettig, R.; Virtanen, S. Time-dependent electrochemical characterization of the corrosion of a magnesium rare-earth alloy in simulated body fluids. J. Biomed. Mater. Res. Part A 2008, 85, 167-175. [CrossRef] [PubMed]

48. Xin, Y.; Hu, T.; Chu, P.K. In vitro studies of biomedical magnesium alloys in a simulated physiological environment: A review. Acta Biomater. 2011, 7, 1452-1459. [CrossRef] [PubMed]

49. Abe, Y.; Kokubo, T.; Yamamuro, T. Apatite coating on ceramics, metals and polymers utilizing a biological process. J. Mater. Sci. Mater. Med. 1990, 1, 233-238. [CrossRef]

50. Tanahashi, M.; Yao, T.; Kokubo, T.; Minoda, M.; Miyamoto, T.; Nakamura, T.; Yamamuro, T. Apatite Coating on Organic Polymers by a Biomimetic Process. J. Am. Ceram. Soc. 1994, 77, 2805-2808. [CrossRef]

51. Oyane, A.; Minoda, M.; Miyamoto, T.; Nakanishi, K.; Masakazu, K.; Kokubo, T.; Nakamura, T. Apatite Formation on Ethylene-Vinyl Alcohol Copolymer Modified with Silane Coupling Agent and Calcium Silicate. Key Eng. Mater. 2000, 192-195, 713-716. [CrossRef]

52. Krasner, P.; Person, P. Preserving Avulsed Teeth for Replantation. J. Am. Dent. Assoc. 1992, 123, 80-88. [CrossRef] [PubMed]

53. Marques, P.A.A.P.; Magalhães, M.C.F.; Correia, R.N. Inorganic plasma with physiological $\mathrm{CO}_{2} / \mathrm{HCO}_{3}-$ buffer. Biomaterials 2003, 24, 1541-1548. [CrossRef]

54. Sigel, H.; Scheller, K.H.; Prijs, B. Metal ion/buffer interactions. Stability of alkali and alkaline earth ion complexes with triethanolamine (tea), 2-amino-2(hydroxymethyl)-1,3-propanediol (tris)and 2-[bis(2-hydroxyethyl)-amino] 2(hydroxymethyl)-1,3-propanediol (Bistris) in aqueous and mixed solvents. Inorg. Chim. Acta 1982, 66, 147-155.

55. Marques, P.A.A.P.; Serro, A.P.; Saramago, B.J.; Fernandes, A.C.; Magalhães, M.C.F.; Correia, R.N. Mineralisation of two calcium phosphate ceramics in biological model fluids. J. Mater. Chem. 2003, 13, 1484-1490. [CrossRef]

56. Harandi, S.E.; Singh Raman, R.K. Appropriate Mechanochemical Conditions for Corrosion-Fatigue Testing of Magnesium Alloys for Temporary Bioimplant Applications. JOM 2015, 67, 1137-1142. [CrossRef]

57. Xin, Y.; Huo, K.; Tao, H.; Tang, G.; Chu, P.K. Influence of aggressive ions on the degradation behavior of biomedical magnesium alloy in physiological environment. Acta Biomater. 2008, 4, 2008-2015. [CrossRef] [PubMed]

58. Song, G.; Atrens, A. Understanding Magnesium Corrosion-A Framework for Improved Alloy Performance. Adv. Eng. Mater. 2003, 5, 837-858.

59. William, D.F.; William, R.L.; Ratner, B.D.; Hoffman, A.S.; Schoen, F.J.; Lemons, J.E. Biomaterials Science, 2nd ed.; Elsevier: San Diego, CA, USA, 2004.

60. Yamamoto, A.; Hiromoto, S. Effect of inorganic salts, amino acids and proteins on the degradation of pure magnesium in vitro. Mater. Sci. Eng. C 2009, 29, 1559-1568. [CrossRef]

61. Song, G.L.; Xu, Z. 5-Surface processing and alloying to improve the corrosion resistance of magnesium (Mg) alloys. In Corrosion Prevention of Magnesium Alloys; Song, G.-L., Ed.; Woodhead Publishing: Cambridge, UK, 2013; pp. 110-134.

62. Chakraborty Banerjee, P.; Singh Raman, R.K.; Durandet, Y.; McAdam, G. Influence of Laser Processing Parameters on Microstructure and Corrosion Kinetics of Laser-Treated ZE41 Magnesium Alloy. Metall. Mater. Trans. A 2013, 44, 2346-2357. [CrossRef]

63. Banerjee, P.C.; Raman, R.K.S.; Durandet, Y.; McAdam, G. Electrochemical investigation of the influence of laser surface melting on the microstructure and corrosion behaviour of ZE41 magnesium alloy-An EIS based study. Corros. Sci. 2011, 53, 1505-1514. [CrossRef]

64. Chakraborty Banerjee, P.; Singh Raman, R.K. Electrochemical impedance spectroscopic investigation of the role of alkaline pre-treatment in corrosion resistance of a silane coating on magnesium alloy, ZE41. Electrochim. Acta 2011, 56, 3790-3798. [CrossRef] 
65. Alabbasi, A.; Liyanaarachchi, S.; Kannan, M.B. Polylactic acid coating on a biodegradable magnesium alloy: An in vitro degradation study by electrochemical impedance spectroscopy. Thin Solid Films 2012, 520, 6841-6844. [CrossRef]

66. Ostrowski, N.J.; Lee, B.; Roy, A.; Ramanathan, M.; Kumta, P.N. Biodegradable poly(lactide-co-glycolide) coatings on magnesium alloys for orthopedic applications. J. Mater. Sci. Mater. Med. 2013, 24, 85-96. [CrossRef]

67. Li, L.-H.; Sankara Narayanan, T.S.N.; Kim, Y.K.; Kong, Y.-M.; Park, I.S.; Bae, T.S.; Lee, M.H. Deposition of microarc oxidation-polycaprolactone duplex coating to improve the corrosion resistance of magnesium for biodegradable implants. Thin Solid Films 2014, 562, 561-567. [CrossRef]

68. Shi, P.; Niu, B.; Shanshan, E.; Chen, Y.; Li, Q. Preparation and characterization of PLA coating and PLA/MAO composite coatings on AZ31 magnesium alloy for improvement of corrosion resistance. Surf. Coat. Technol. 2015, 262, 26-32. [CrossRef]

69. Tian, P.; Xu, D.; Liu, X. Mussel-inspired functionalization of PEO/PCL composite coating on a biodegradable AZ31 magnesium alloy. Colloids Surf. B Biointerfaces 2016, 141, 327-337. [CrossRef]

70. Hanas, T.; Sampath Kumar, T.S.; Perumal, G.; Doble, M. Tailoring degradation of AZ31 alloy by surface pre-treatment and electrospun PCL fibrous coating. Mater. Sci. Eng. C 2016, 65, 43-50. [CrossRef] [PubMed]

71. Xi, Z.; Tan, C.; Xu, L.; Meng, Y.; Zhang, C.; Yang, N.; Li, Q. A novel functional HPPS/PCL/ZnO composite layer on AZ91 for anticorrosion. Mater. Lett. 2015, 148, 134-137. [CrossRef]

72. Kim, J.; Mousa, H.M.; Park, C.H.; Kim, C.S. Enhanced corrosion resistance and biocompatibility of AZ31 Mg alloy using PCL/ZnO NPs via electrospinning. Appl. Surf. Sci. 2017, 396, 249-258. [CrossRef]

73. Ravenscroft-Chang, M.S.; Stohlman, J.M.; Molnar, P.; Natarajan, A.; Canavan, H.E.; Teliska, M.; Stancescu, M.; Krauthamer, V.; Hickman, J.J. Altered calcium dynamics in cardiac cells grown on silane-modified surfaces. Biomaterials 2010, 31, 602-607. [CrossRef] [PubMed]

74. Jiang, G.; Evans, M.E.; Jones, I.A.; Rudd, C.D.; Scotchford, C.A.; Walker, G.S. Preparation of poly( $\varepsilon$-caprolactone)/continuous bioglass fibre composite using monomer transfer moulding for bone implant. Biomaterials 2005, 26, 2281-2288. [CrossRef] [PubMed]

75. Müller, R.; Abke, J.; Schnell, E.; Macionczyk, F.; Gbureck, U.; Mehrl, R.; Ruszczak, Z.; Kujat, R.; Englert, C.; Nerlich, M.; et al. Surface engineering of stainless steel materials by covalent collagen immobilization to improve implant biocompatibility. Biomaterials 2005, 26, 6962-6972. [CrossRef] [PubMed]

76. Ren, L.; Tsuru, K.; Hayakawa, S.; Osaka, A. Novel approach to fabricate porous gelatin-siloxane hybrids for bone tissue engineering. Biomaterials 2002, 23, 4765-4773. [CrossRef]

77. Ren, L.; Tsuru, K.; Hayakawa, S.; Osaka, A. Synthesis and Characterization of Gelatin-Siloxane Hybrids Derived through Sol-Gel Procedure. J. Sol-Gel Sci. Technol. 2001, 21, 115-121. [CrossRef]

78. Liu, X.; Yue, Z.; Romeo, T.; Weber, J.; Scheuermann, T.; Moulton, S.; Wallace, G. Biofunctionalized anti-corrosive silane coatings for magnesium alloys. Acta Biomater. 2013, 9, 8671-8677. [CrossRef]

79. Gaur, S.; Singh Raman, R.K.; Khanna, A.S. In vitro investigation of biodegradable polymeric coating for corrosion resistance of Mg-6Zn-Ca alloy in simulated body fluid. Mater. Sci. Eng. C 2014, 42, 91-101. [CrossRef] [PubMed]

80. Gaur, S.; Nigam, S.; Khanna, A.S.; Raman, R.K.S. Silane-Coated Magnesium Implants with Improved In-Vitro Corrosion Resistance and Biocompatibility. J. Mater. Sci. Surf. Eng. 2016, 4, 415-424.

81. Córdoba, L.C.; Montemor, M.F.; Coradin, T. Silane/ $\mathrm{TiO}_{2}$ coating to control the corrosion rate of magnesium alloys in simulated body fluid. Corros. Sci. 2016, 104, 152-161. [CrossRef]

82. Al-Saadi, S.; Banerjee, P.C.; Anisur, M.; Raman, R.S. Hexagonal Boron Nitride Impregnated Silane Composite Coating for Corrosion Resistance of Magnesium Alloys for Temporary Bioimplant Applications. Metals 2017, 7, 518. [CrossRef]

83. Paital, S.R.; Dahotre, N.B. Calcium phosphate coatings for bio-implant applications: Materials, performance factors, and methodologies. Mater. Sci. Eng. R Rep. 2009, 66, 1-70. [CrossRef]

84. Song, Y.; Zhang, S.; Li, J.; Zhao, C.; Zhang, X. Electrodeposition of Ca-P coatings on biodegradable Mg alloy: In vitro biomineralization behavior. Acta Biomater. 2010, 6, 1736-1742. [CrossRef] [PubMed]

85. Liu, G.; Wang, J.; Bian, K.; Zhu, P. Preparation and characterization of nanostructured dibasic calcium phosphate coating on magnesium alloy wire. Mater. Lett. 2017, 209, 323-326. [CrossRef]

86. Jafari, S.; Singh Raman, R.K. In-vitro biodegradation and corrosion-assisted cracking of a coated magnesium alloy in modified-simulated body fluid. Mater. Sci. Eng. C 2017, 78, 278-287. [CrossRef] [PubMed] 
87. Kannan, M.B. Enhancing the performance of calcium phosphate coating on a magnesium alloy for bioimplant applications. Mater. Lett. 2012, 76, 109-112. [CrossRef]

88. Wang, H.X.; Guan, S.K.; Wang, X.; Ren, C.X.; Wang, L.G. In vitro degradation and mechanical integrity of $\mathrm{Mg}-\mathrm{Zn}-\mathrm{Ca}$ alloy coated with Ca-deficient hydroxyapatite by the pulse electrodeposition process. Acta Biomater. 2010, 6, 1743-1748. [CrossRef]

89. Meng, E.C.; Guan, S.K.; Wang, H.X.; Wang, L.G.; Zhu, S.J.; Hu, J.H.; Ren, C.X.; Gao, J.H.; Feng, Y.S. Effect of electrodeposition modes on surface characteristics and corrosion properties of fluorine-doped hydroxyapatite coatings on Mg-Zn-Ca alloy. Appl. Surf. Sci. 2011, 257, 4811-4816. [CrossRef]

90. Surmeneva, M.A.; Mukhametkaliyev, T.M.; Khakbaz, H.; Surmenev, R.A.; Bobby Kannan, M. Ultrathin film coating of hydroxyapatite (HA) on a magnesium-calcium alloy using RF magnetron sputtering for bioimplant applications. Mater. Lett. 2015, 152, 280-282. [CrossRef]

91. Mukhametkaliyev, T.M.; Surmeneva, M.A.; Vladescu, A.; Cotrut, C.M.; Braic, M.; Dinu, M.; Vranceanu, M.D.; Pana, I.; Mueller, M.; Surmenev, R.A. A biodegradable AZ91 magnesium alloy coated with a thin nanostructured hydroxyapatite for improving the corrosion resistance. Mater. Sci. Eng. C 2017, 75, 95-103. [CrossRef]

92. Ren, Y.; Zhou, H.; Nabiyouni, M.; Bhaduri, S.B. Rapid coating of AZ31 magnesium alloy with calcium deficient hydroxyapatite using microwave energy. Mater. Sci. Eng. C 2015, 49, 364-372. [CrossRef]

93. Abdal-hay, A.; Amna, T.; Lim, J.K. Biocorrosion and osteoconductivity of PCL/nHAp composite porous film-based coating of magnesium alloy. Solid State Sci. 2013, 18, 131-140. [CrossRef]

94. Abdal-hay, A.; Barakat, N.A.M.; Lim, J.K. Hydroxyapatite-doped poly(lactic acid) porous film coating for enhanced bioactivity and corrosion behavior of AZ31 Mg alloy for orthopedic applications. Ceram. Int. 2013, 39, 183-195. [CrossRef]

95. Zomorodian, A.; Santos, C.; Carmezim, M.J.; Moura e Silva, T.; Fernandes, J.C.S.; Montemor, M.F. "In-vitro" corrosion behaviour of the magnesium alloy with $\mathrm{Al}$ and $\mathrm{Zn}$ (AZ31) protected with a biodegradable polycaprolactone coating loaded with hydroxyapatite and cephalexin. Electrochim. Acta 2015, 179, 431-440. [CrossRef]

96. Kalbacova, M.; Broz, A.; Kong, J.; Kalbac, M. Graphene substrates promote adherence of human osteoblasts and mesenchymal stromal cells. Carbon 2010, 48, 4323-4329. [CrossRef]

97. Lee, W.C.; Lim, C.H.Y.X.; Shi, H.; Tang, L.A.L.; Wang, Y.; Lim, C.T.; Loh, K.P. Origin of Enhanced Stem Cell Growth and Differentiation on Graphene and Graphene Oxide. ACS Nano 2011, 5, 7334-7341. [CrossRef]

98. Nayak, T.R.; Andersen, H.; Makam, V.S.; Khaw, C.; Bae, S.; Xu, X.; Ee, P.-L.R.; Ahn, J.-H.; Hong, B.H.; Pastorin, G.; et al. Graphene for Controlled and Accelerated Osteogenic Differentiation of Human Mesenchymal Stem Cells. ACS Nano 2011, 5, 4670-4678. [CrossRef]

99. Kim, S.; Ku, S.H.; Lim, S.Y.; Kim, J.H.; Park, C.B. Graphene-Biomineral Hybrid Materials. Adv. Mater. 2011, 23, 2009-2014. [CrossRef] [PubMed]

100. Lahiri, D.; Dua, R.; Zhang, C.; de Socarraz-Novoa, I.; Bhat, A.; Ramaswamy, S.; Agarwal, A. Graphene Nanoplatelet-Induced Strengthening of UltraHigh Molecular Weight Polyethylene and Biocompatibility In vitro. ACS Appl. Mater. Interfaces 2012, 4, 2234-2241. [CrossRef] [PubMed]

101. Li, M.; Liu, Q.; Jia, Z.; Xu, X.; Cheng, Y.; Zheng, Y.; Xi, T.; Wei, S. Graphene oxide/hydroxyapatite composite coatings fabricated by electrophoretic nanotechnology for biological applications. Carbon 2014, 67, 185-197. [CrossRef]

102. Gao, F.; Xu, C.; Hu, H.; Wang, Q.; Gao, Y.; Chen, H.; Guo, Q.; Chen, D.; Eder, D. Biomimetic synthesis and characterization of hydroxyapatite/graphene oxide hybrid coating on $\mathrm{Mg}$ alloy with enhanced corrosion resistance. Mater. Lett. 2015, 138, 25-28. [CrossRef]

103. Santos, C.; Piedade, C.; Uggowitzer, P.J.; Montemor, M.F.; Carmezim, M.J. Parallel nano-assembling of a multifunctional GO/HapNP coating on ultrahigh-purity magnesium for biodegradable implants. Appl. Surf. Sci. 2015, 345, 387-393. [CrossRef]

(C) 2019 by the authors. Licensee MDPI, Basel, Switzerland. This article is an open access article distributed under the terms and conditions of the Creative Commons Attribution (CC BY) license (http:/ / creativecommons.org/licenses/by/4.0/). 